\title{
A Review on the Effect of Various Chemical Treatments on the Mechanical Properties of Renewable Fiber-Reinforced Composites
}

\author{
M. Aravindh, ${ }^{1}$ S. Sathish, ${ }^{1}$ R. Ranga Raj $\mathbb{D},{ }^{2}$ Alagar Karthick $\mathbb{D},{ }^{3,4}$ V. Mohanavel $\mathbb{D},{ }^{5}$ \\ Pravin P. Patil, ${ }^{6}$ M. Muhibbullah $\left(D,{ }^{7}\right.$ and Sameh M. Osman ${ }^{8}$ \\ ${ }^{1}$ Centre for Machining and Materials Testing, KPR Institute of Engineering and Technology, Coimbatore 641407, India \\ ${ }^{2}$ Department of Aeronautical Engineering, Sri Ramakrishna Engineering College, Coimbatore 641 022, Tamilnadu, India \\ ${ }^{3}$ Renewable Energy Lab, Department of Electrical and Electronics Engineering, KPR Institute of Engineering and Technology, \\ Coimbatore 641407, Tamilnadu, India \\ ${ }^{4}$ Departamento de Quimica Organica, Universidad de Cordoba, EdificioMarie Curie (C-3), Ctra Nnal IV-A,Km 396, \\ E14014 Cordoba, Spain \\ ${ }^{5}$ Centre for Materials Engineering and Regenerative Medicine, Bharath Institute of Higher Education and Research, \\ Chennai 600073, Tamilnadu, India \\ ${ }^{6}$ Department of Mechanical Engineering, Graphic Era Deemed to be University, Bell Road, Clement Town, 248002 Dehradun, \\ Uttarakhand, India \\ ${ }^{7}$ Department of Electrical and Electronic Engineering, Bangladesh University, Dhaka 1207, Bangladesh \\ ${ }^{8}$ Chemistry Department, College of Science, King Saud University, P.O. Box 2455, Riyadh 11451, Saudi Arabia
}

Correspondence should be addressed to M. Muhibbullah; m.muhibbullah@bu.edu.bd

Received 20 November 2021; Accepted 24 December 2021; Published 25 January 2022

Academic Editor: Lubos Kristak

Copyright $(2022$ M. Aravindh et al. This is an open access article distributed under the Creative Commons Attribution License, which permits unrestricted use, distribution, and reproduction in any medium, provided the original work is properly cited.

Increased environmental concerns and global warming have diverted effort all over the world to focus on renewable and sustainable resources for the next generation of composite products due to their recyclability, renewability, cost effectiveness, and satisfactory mechanical performance. Bio/natural fibers which are environment friendly materials employed as reinforcement have led to developing a biocomposite for reduction in greenhouse emission and carbon footprints. However, biofibers are also having some limitations that need to be addressed including poor compatibility between the reinforcing fiber matrices, high moisture absorption, swelling, poor chemical and fire resistance, and high dispersion of mechanical properties. A lot of research has been performed on physical and mechanical properties of natural fiber composite. Properties of such novel composite mainly depend on adhesion between fiber and matrices. Consequently, poor adhesion, high moisture absorption, and swelling lead to formation of crack in both the matrix and fiber. Therefore, numerous techniques have been tried till date to modify both fiber surfaces to enhance their adhesion and reduce their water absorption. This review article provides comprehensive information about effect of various surface modification techniques that include alkaline, silane, acetylation, permanganate, peroxide, benzoylation, acrylonitrile grafting, maleic anhydride grafted, acrylation, and isocyanate. In addition, the effects of cellulose, hemicellulose, lignin, and pectin of biofibers are also reported. This review concluded that chemical treatment of biofibers with $5 \%$ $\mathrm{NaOH}$ concentration improves the physical, mechanical, and thermal properties of the resulting composites compared to untreated fiber composites. 


\section{Introduction}

Presently, the automotive industries do face many challenges, such as the shortage of supply of fossil fuels, new technological innovations, and environmental sustainability to fight global warming. The above listed factors increase the pressure in the current materials design and manufacturing technologies in automotive industries $[1,2]$. A lightweight material was a necessity for the structural components for lower energy consumption of vehicles. The research community has shifted the focus towards effective utilization of the biofibers extracted from renewable sources. The natural fibers are being employed for application components such as interior dashboard trims for automobiles and household applications $[3,4]$. The utilization of lightweight and lowcost biofibers such as abaca, banana, bamboo, coir, flax, ramie, tea leaf, pineapple, sisal, kenaf, and jute was already tried as reinforcements in the polymer matrix for composite materials used for manufacturing automobile components [5-7]. The biodegradability of biofibers is associated with physical, chemical, mechanical, thermal, and moisture conditions which have increased their scope of use in numerous applications [8, 9]. Based on the usage and utilization, usually biofibers are classified as primary and secondary fibers. Primary fibers include jute, sisal, kenaf, and hemp fibers, where these fibers are grown for their fiber contents. Secondary fibers include agroresidues, coir fibers, and pineapple fibers, which are fibers obtained from plant by-products. These fibers can be further classified into six types: bast fibers (flax, jute, etc.), leaf fibers (sisal, pineapple leaf fiber), seed fibers (cotton, coir), core fibers (hemp, kenaf), grass and reed fibers (wheat, corn, and rice), and all other types (wood and roots). The structure and chemical constituents of biofiber depend on several factors like extraction process, location of plant growth, climate, plant age, and plant nature [10-13]. When compared to synthetic glass fibers, natural fibers have better specific modulus. The cost saving on the material owing to the use of plant based fibers and nonabrasive nature of the materials during mixing and moulding makes the natural fibers a promising reinforcement for polymer composites [14]. These advantages make the biofiber be employed in any application like automobile, domestic utilities, and distinction $[15,16]$. The biofiber composites were used in many places because of the following merits: eco-friendly nature, easy availability, low weight, good strength, low cost, and ease of manufacturing process [17-19]. The foremost disadvantages of the biofibers are that they absorb more moisture. The moisture absorption of biofibers has several unfavourable effects on their properties and thus affects the long-term performance of the composites [20]. The mechanical and thermal performances of bio/natural fibers reinforced composites (NFRC) were influenced by weight/volume fraction of fiber, fiber orientation, selection of chemical treatment method, and physical characteristics of the natural fiber [21-23]. However, the water absorption and thermal stability of the composite laminate were noticed to reduce with increase in weight fraction of fiber [24-28]. The natural fibrils are constituted of cellulose, hemicellulose, and lignin in varying percentages.
In addition, the natural fibers do have other substances like pectin, wax, and other water soluble compositions. The cellulose is enclosed in soft lignin, while hemicellulose forms the ancillary layer of the fiber material [29]. Ishak et al. [30] studied the tensile strength of bagasse fiber obtained from plants of different heights. The tensile properties were specifically high for the fibers extracted from bottom of tree due to their chemical composition, particularly cellulose, hemicellulose, and lignin. Moisture absorption of the natural composites was increased when fiber content increased because of its higher cellulose content amount. George et al. [31] stated that the biofibers have high amount of hydrophilic property which leads to poor adhesion properties between the hydrophilic fiber and hydrophobic matrix. Hydrophilicity is the stronger affinity of the fibers towards moisture. The major disadvantages of natural fiber are poor adhesion between fiber and matrix, presence of cellulose content, moisture absorption, and voids at interface between fiber and matrix which results in dimensional inaccuracy, thus affecting the mechanical properties [32-35]. In addition to that, presence of high moisture content in fiber leads to swelling of fiber and matrix within composites resulting in dimensional instability. This disadvantage and limitation can be overcome by chemical treatments. The chemical treatments are carried out to reduce the hydrophilic nature of fiber but the surface treatments not only modify the fiber surface but also increase the fiber strength leading to the improvement of adhesion between fiber and matrix [36-38]. The most common chemical treatment and surface treatment methods are silane, alkaline, acetylene, maleated coupling, anhydride, and benzolytation. Optimization of fiber and matrix is aimed to improve the adhesion, surface tension, interfacial strength, and wettability that offer good surface roughness leading to good bond [39]. These could be done by adding suitable compatibilizer/coupling agent and chemically treating the fiber. Recent literature survey showed that several works have been published on different natural fibers extracted from renewable sources which are used as reinforcement with polymer matrix over a wide dimension of applications. This survey depicts various surface treatments done to enhance the properties of the fibers and for enrichment in mechanical properties of the composites in contrast with untreated fiber-reinforced polymer composites. Therefore we summarized the major findings on different types of chemical treatments and surface treatments.

\section{Constitution of Biofiber}

2.1. Cellulose. In plant based fibers, cellulose is the primary structural constituent and the cellulose portion influences the mechanical properties of the lignocellulose fibers. The cellulose is the fundamental constituent which is liable for the strength of the plant fibers and variance in strength may be due to growth conditions of the plant and soil nature. Cellulose is a lined, semicrystalline polysaccharide build-up of polymer links compromising the recurring modules of anhydroglucose grouped via 1,4- $\beta$-D-glucosidase. The recurring modules of the monomers are termed as degree of 
polymerization. The monomers of glucose in the chain of cellulose result in formation of the hydrogen bonds among the link forming fibers as well as associated chains. The binding of intramolecular and intermolecular hydrogen regions results in development of linear crystalline structure called cellulose.

2.2. Hemicellulose. Hemicellulose is a multidiverged polysaccharide made up of many distinctive glucose monomers, while cellulose is composed of only single $4-\beta D$-glucopyranose repeating units. When compared to cellulose, the constituent of hemicellulose varies from one plant to other. The amorphous nature of the hemicellulose is confirmed by its high degree of chain grouping.

2.3. Lignin. Lignin is an intricate hydrocarbon polymer composed of aliphatic and aromatic elements. In addition to the cellulose, lignin is another important constituent in the lignocellulose fibril. The lignin binds the fibers together to make the fiber surface be stiffer enough by giving compression strength to the plant. The chemical composition of lignin is made of phenylpropane elements obtained from an enzyme-initiated dehydrogenate polymerization of three distinct constituents which are trans-p-coumaryl, transconiferyl, and trans-sinapyl.

2.4. Pectin. Pectin is an element of acidic polysaccharides with complex structure. The main constituents of pectin are homopolymeric acid and partial residues of methylated poly- $\alpha$-(1-4)-D-galacturonic acid. When treated with alkali or ammonium hydroxide, pectin will become a water soluble polymer. The role of pectin is to function as cementing element among the plant fibrils which binds with other constituents to form stacks. Higher amount of pectin is present in the primary cell wall and the middle lamella of lignocellulosic fibril. During the process of retting, most of the pectin contents get removed from the natural fiber. Only after the removal of pectin does the natural fiber get qualified to be employed as reinforcement material with polymer matrices. Pectin is another component which makes the cellulose fibers get attached to all other constituents of the fiber. When compared to cellulose, lignin and pectin are the weaker amorphous polymers [40].

\section{Effect of Various Chemical Treatments on the Mechanical Properties of Composites}

Kobayashi et al. [41] discussed the mechanical properties of the hemp fiber-reinforced composite fabrication, and the hemp fiber was chemically treated to improve compatibility between fiber and the matrix. The authors found that the physical and mechanical properties of the natural and synthetic fibers were influenced by climate/natural/environmental changes. Hence, the surface of the hemp fiber was treated by chemical treatment process like acetyl, alkali, and silane. Alam et al. [42] explored the tensile strength of a new composites, combined with untreated kenaf, treated kenaf, jute fiber, and jute rope. They observed that the tensile strengths of kenaf and jute fiber are higher than that of jute rope. Similarly the water absorption properties of treated fiber were higher than those of untreated fibers. The stress transfer capacity of the fiber gets improved as a result of micro void exclusion and the fiber surfaces turn more uniform. The diameter of the fiber is also improved owing to the axial splitting of the fibrils [43]. Wang et al. [44] studied the feasibility of using coffee hull as reinforcement member with high density polyethylene matrix. Improvement in mechanical characteristics of the coffee hull polyethylene composites was compared against various chemical modifications done on the coffee hull powder. It was found that coffee hull powder subjected to calcium hydroxide treatment resulted in maximum strength of the composites. The fiber loading was found to increase up to $10 \mathrm{wt} \%$ above which the tensile strength decreases, whereas the flexural strength was found to be prominent for coffee hull treated with maleic anhydride grafted polypropylene. The moisture absorption property was found to be significant for the composite subjected to calcium hydroxide treatment. Therefore it was concluded that coffee hull powder could be a possible alternate for synthetic fiber. Rout et al. [45] conducted morphology analysis of palm tree leaf stalk fibers, where the SEM images confirmed the removal of wax, oil, and hemicellulose content from treated fibers. The cleaner surfaces besides pores were noticed in treated fibers compared to untreated fibers. The natural plant fibers have many advantages; there are also a few limitations which have to be studied. The major limitation of natural plant fibers is their hydrophilic nature which restricts the use of the fibers as reinforcement in PMC. The inappropriateness between the hydrophilic fibers and hydrophobic matrix results in swelling due to moisture absorption and it shows the poor interfacial bonding between matrix and the fibers [46-48]. Improvement was found in the interfacial bonding between the fiber and matrix due to the chemical treatments of fibers which also reduce the hydrophilicity, fiber surface cleanness, the moisture absorption, and improvement in the surface roughness [49]. Various natural fiber surface treatments like alkaline, silane, acetylation, and preimpregnation with polyethylene solution resulted in the enhancement of strength due to increase of interfacial bonding between fiber and matrix [50]. Venkatesha Gupta et al. [51] developed a new composite material which had the highest strength to weight ratio in comparison to existing composite materials. Sisal and hemp fibers were reinforced with epoxy matrix prepared using compression moulding method according to ASTM standard. For alkali treatment, $\mathrm{NaOH}$ (sodium hydroxide) was used and the amount of reinforcement was changed from $10 \%$ to $50 \%$ by weight. After the specimen was prepared, various mechanical properties were investigated and it was proved that the prepared specimen was better in terms of mechanical properties. Athipathi and Hegde Sowmitha Vijay [52] discussed the experimental evaluation based mechanical properties of coir and Roystonea regiaepoxy laminate with various fiber contents ratios. Orientation of the fiber was maintained as $0^{\circ}, 45^{\circ}$, and $90^{\circ}$. From the results, three different points were observed. The 
untreated matrix-material based composite exhibits high tensile strength, high flexural strength, and high impact strength. The fibers were subjected to $30 \% \mathrm{NaOH}$ solution treatment for $1 \mathrm{~h}$. The mechanical and electrical properties of composites with treated fibers were compared with those of untreated fiber composites. The modification of plant based lignocellulose fibrils by sodium hydroxide is the most widely adopted technique to alter the cellulose molecular portion of the natural fiber. The coir/epoxy composites were used in the seat cushions, mirror casing, storage tank, post boxes, helmet casing, brushes, ropes, bags, brooms, door shutters, and building panels. The alkali treatment results in formation of amorphous region from the densely packed crystalline cellulose structure. The alkali-sensitive hydroxyl units existing in the natural fibers were removed, which further react with the water molecules. Thereby the moisture resistance property of the fiber improved. The alkali treatment also removes some portions of hemicellulose, lignin, pectin, wax, and other surface related impurities present in the natural fiber $[53,54]$. Thereby the effective bonding between the fiber and the matrix is also enriched and the mechanical and thermal properties of the composites are improved. When the percentage of alkali treatment is increased, excess delignification of the natural fiber occurs, which leads to damage of fibers, and the mechanical properties of the fibers get reduced [55]. Alkalized lignocellulose fibers have reduced lignin content, partial removal of wax and oil covering substances happens, and disintegration of crystalline cellulose occurs.

More research articles have been published on the influence of mercerization on the mechanical and thermal properties of lignocellulose fiber-reinforced polymer matrix composites $[56,57]$. Sathish et al. [53] explored the influence of mercerization of date palm fibers on the mechanical, thermal, and morphological properties. It was reported that $5 \%$ of $\mathrm{NaOH}$ concentration enhanced mechanical and thermal behaviour of the composites. When the percentage of sodium hydroxide was increased to $10 \%$, deterioration on the properties was observed owing to the damage of fibers at increased concentration. The thermal resistance of the fiber was also improved due to the pulling out of waxy layers and various surface impurities present in the date palm fibers. Chen et al. [58] investigated the wettability and thermal stability of bamboo fibers exposed to alkali treatment. The percentage of alkali treatment was varied; it was found that surface roughness of the bamboo fiber was increased and found to be optimum at $15 \%$ of $\mathrm{NaOH}$ treatment. The thermal stability and wettability were also found to be promising for the similar alkali concentration. Reddy et al. [59] investigated the tensile and structural properties of borassus fruit fine fibers subjected to $5 \%$ of alkali treatment under different treatment time. The crystallinity of the fibers was analysed by X-ray diffraction technique. The removal of amorphous hemicellulose substance was witnessed by FTIR analysis. The concentration time of 8 hours resulted in optimum fiber properties. It was also found that the borassus fibers will be a suitable reinforcement for the manufacturing of green composites. Balaji and Nagarajan [60] investigated the tensile and chemical behaviour of cellulose fibers extracted from saharan Aloe vera cactus leaves exposed to mercerization treatment. The fibers exposed to mercerization resulted in removal of hemicellulose, lignin, wax, and other surface related impurities present in the fibers. It was also found that the hydrophobic nature of the lignocellulose fibrils is lowered and interfacial adherence among the fibrils and the matrix enhanced. Increase in thermal stability of the fibrils was witnessed by TG analysis. The SEM analysis also confirmed the removal of hemicellulose, lignin, wax, and other layers present in the fibers. Finally, it was found that natural fiber extracted from saharan Aloe vera cactus leaves was found to be a suitable alternate to synthetic fibers for reinforcement with polymer matrix. Dawit et al. [61] explored the property of Acacia tortilis fibrils extracted from the barks of Acacia tortilis tree. The extraction of fiber was based on natural water based retting. The extracted fibers were subjected to mercerization treatment with $10 \%$ and $20 \%$ of $\mathrm{NaOH}$ solution. The alkalization of the fiber resulted in removal of hemicellulose, lignin, wax, and other surface related impurities present in the fiber. As the percentage of alkali treatment is increased to $20 \%$, decrease in tensile strength of the fibrils was noted. This phenomenon could be explained as follows: when the concentration of alkali solution exceeds the limit, the diameter of the fiber gets reduced even further, which results in reduced tensile strength. It was also concluded that Acacia tortilis fiber could be a viable alternate for manmade fiber in polymer composite applications. Narayanasamy et al. [62] explored the possibility of lignocellulose fibril extracted from Calotropis gigantea fruit bunch as a possible alternate for artificial fiberreinforced polymer composites. The fibers were extracted from the fruits of Calotropis gigantea fruit bunch through retting process. Then the extracted fibers were mercerized with $5 \%$ of $\mathrm{NaOH}$. XRD and FTIR analysis revealed the removal of hemicellulose, lignin, wax, and other surface related impurities existing in the fibers. The thermal stability of the fibrils was also enriched by the influence of alkali treatment, which is inferred by TG analysis. Finally SEM analysis revealed that the surface of fibers was rougher due to alkali treatment. Negawo et al. [63] researched the effect of alkali modification on the Ensete stem fibrils obtained from the Ethiopian Ensete ventricosum plant. The fibers were subjected to $2.5 \%, 5 \%$, and $7.5 \%$ of mercerization. The mercerization resulted in removal of lignin, wax, and hemicellulose existing in the fibrils. The $5 \%$ mercerized fibers exhibited better properties when compared with untreated fibrous composites owing to the enhanced interfacial adherence between the fiber and the matrix. The 5\% alkalized fibers exhibited better mechanical properties under static and dynamic conditions. From the experimentation, it was also concluded that Ensete stem fiber could be a possible alternate to synthetic fiber-reinforced polymer composites for wide assortment of applications. Reddy et al. [64] studied the influence of $\mathrm{NaOH}$ and $\mathrm{KOH}$ fiber surface modifications on the mechanical properties of Tapsi fiber-reinforced epoxy composites manufactured by hand layup technique. Initially the fibrils were pretreated with $5 \%$ of concentrations for two hours. Composites were manufactured by varying the fiber weight fraction. Tensile and flexural test performed on the 
composite samples revealed that composites with $15 \%$ of fibers exhibited higher properties for $\mathrm{NaOH}$-treated fibers when compared to $\mathrm{KOH}$-treated fibers. FTIR analysis revealed the removal of functional groups present in the fibers and XRD analysis revealed the improvement of crystallinity index and size for $\mathrm{NaOH}$-treated fiber-reinforced composite samples when compared to $\mathrm{KOH}$-treated sample. SEM analysis revealed fiber pull-out as a result of improper fibril wetting, which resulted in poor adherence between the interfaces of fiber and matrix in the composites. Senthilkuamr et al. [65] reviewed the mechanical properties of sisal fiber-reinforced polymer composites. The sisal fibers have been extracted by the process of decortication and the extracted sisal fibers were exposed to chemical treatment like alkalization and coupling agents. The pretreated sisal fiber showed improvement in mechanical, hydrophilic tendency resulting in effective bonding between the interfaces of fiber and polymer matrix. The mechanical properties of the developed composites depend on different characteristics like fiber length, fiber orientation, fiber volume fraction, and several other parameters. Appreciable enhancement in mechanical properties was found owing to the chemical modifications on the surface of sisal fibers. Overall, it was concluded that the enrichment in properties of the sisal fiber-reinforced composites depends on surface treatment concentration type and time; beyond the concentration level, deterioration in properties of the fibers was noticed. It was also concluded that impact strength of the sisal fiber composites decreased as a result of chemical modifications done on the sisal fibers. Balaji et al. [66] explored the influence of fiber content on the mechanical properties of the alkali-treated bagasse fiber reinforced with cashew nut shell liquid. Initially the fibers were chopped to 10 and $20 \mathrm{~mm}$ and the composites were prepared by compression moulding technique by varying the fiber volume fraction as $0,5,10,15$, and $20 \mathrm{wt} \%$. The tensile and flexural test revealed that maximum strength was attained for $15 \mathrm{wt} \%$ of fiber-reinforced composites. FTIR analysis revealed the removal of functional groups present in the fibers owing to the alkali treatment of sugarcane bagasse fiber. The thermal stability of the fibers was also enhanced due to the mercerization and SEM analysis revealed the enhanced interfacial adherence between the fiber and the matrix which resulted in the homogeneous nature of composite. Komal et al. [67] investigated the prominence of alkalization done on the surface of banana fibers. The surface modified banana fibers were reinforced with polypropylene and then the tensile, flexural, and impact strength and degradation behaviour were studied for untreated and surface modified banana fiber-reinforced polypropylene composites. Thermogravimetric analysis revealed removal of hemicellulose, lignin, pectin, wax, and other surface related impurities present in the banana fiber as a result of mercerization. Significant enhancement in tensile and flexural strength was found between untreated and pretreated banana fiber-reinforced polypropylene composites. Improvement of impact strength by $11.5 \%$ was observed for untreated and mercerized banana fiber-reinforced polypropylene composites. The tested composite samples were subjected to morphology analysis by scanning electron microscope to study the fracture behaviour of the composite samples. Fiber pull-outs were observed in untreated banana fiber-reinforced polypropylene composite; as a result, tensile and flexural strength of the composites decreased in contrast with alkali-treated and untreated banana fiber-reinforced polypropylene composite. Marginal reduction in weight loss of the samples was also observed. Alkali-treated banana fiber-reinforced polypropylene composites absorbed less water as the hydrophilic tendency of the fiber was altered by alkali treatment, whereas the untreated banana fiber-reinforced polypropylene composites absorbed water due to higher hydrophilic tendency. Ameer et al. [68] explored the mechanical and moisture characteristics of hydrophilic modified jute fiber-reinforced unsaturated polyester composites. The extracted jute fiber was exposed to mercerization treatment to improve the hydrophilic tendency. Better interlocking in the middle of fiber and matrix was attained by the removal of amorphous substances present in the jute fibers. The mercerization treatment resulted in significant reduction in hydrophobic nature of the jute fiber. The mercerized jute composites showed improved mechanical properties in contrast with untreated jute composites. Chin et al. [69] investigated the mechanical and thermal characteristics of bamboo fiberreinforced composites, where the bamboo fibers were exposed to mercerization with different concentrations over varying time. The effect of alkali treatment was inferred with FTIR and XRD analysis. Enhancement in crystal size and crystallinity index was observed by XRD analysis and removal of lignin, cellulose, and other surface related impurities was observed by FTIR analysis. The thermal stability of the composites was also enhanced, which was evident from the thermogravimetric analysis. The composites with $40 \mathrm{wt} \%$ contributed to maximized tensile and flexural properties of the composites. Balaji et al. [66] explored the mechanical properties of sugarcane bagasse fiber-reinforced cardanol composite. Mercerization of fiber resulted in removal of amorphous substances and improved interlocking between the bagasse fiber and cardanol matrix. The composites with $15 \mathrm{wt} \%$ of fiber exhibited better properties. Senthamaraikannan et al. [70] explored the possibility of using Acacia planifrons fibers as possible reinforcement material with polymer matrices. The fibers were extracted by the process of retting. The extracted fibers were subjected to mercerization with varying percentage of sodium hydroxide. It was found that the mercerization leads to improvement of crystallinity index and thermal stability and removal of amorphous substances present in the fibers. The optimal alkali treatment is found to be $5 \%$. Tables 1-10 present the effects of various chemical treatments of biofibers.

Mouhoubi et al. [174] reported the SEM images of alfa fiber with alkali treatment $(5 \% \mathrm{NaOH})$ at different time intervals ( $2 \mathrm{~h}, 4 \mathrm{~h}, 6 \mathrm{~h}$, and $24 \mathrm{~h}$ ). Figures $1(\mathrm{a})-1(\mathrm{e})$ represent the alfa fiber. Figure 1(b) shows the fiber treated with $5 \%$ $\mathrm{NaOH}$ at $2 \mathrm{~h}$. During this time period, the waxy substances in the fiber were removed. Figures $1(\mathrm{c})-1(\mathrm{e})$ show that the fiber resulted in low moisture absorption, removal of extractives, and increase in crystallinity and stiffness. 
TABLE 1: Effect of alkaline treatment on various biofibers.

\begin{tabular}{|c|c|c|c|c|}
\hline $\begin{array}{l}\text { S. } \\
\text { no. }\end{array}$ & Fibers used & Type of chemical treatment & Effects & Ref. \\
\hline 1 & Kenaf & Alkaline treatment & $\begin{array}{l}\text { At } 6 \% \text { concentration of } \mathrm{NaOH} \text { it has good effect on kenaf fiber } \\
\text { resulting in removal of all impurities from the surface. }\end{array}$ & {$[71]$} \\
\hline 2 & $\begin{array}{l}\text { Bamboo, kenaf, hemp, } \\
\text { sisal, jute, and kapok }\end{array}$ & Alkaline treatment & $\begin{array}{l}\text { The treatment removed the noncellulose constituent in fibers } \\
\text { such as lignin, wax, and oils, promoted ionization of hydroxyl } \\
\text { group of cellulose to alkoxide, and reduced the hydroxyl } \\
\text { group content. The treatment improved the surface roughness } \\
\text { and hydrophobicity resulting in good adhesion. }\end{array}$ & {$[72]$} \\
\hline 3 & Pineapple leaf & Alkaline and acetic & $\begin{array}{c}\text { Improvements in tensile strength, impact strength, and } \\
\text { flexural strength. }\end{array}$ & [73] \\
\hline 4 & Abaca & Alkaline and silane treatment & The silane-treated fiber has higher thermal transfer coefficient. & {$[73]$} \\
\hline 5 & Bamboo & Alkaline treatment & $\begin{array}{l}\text { An enhancement in tensile strength by adding } 30 \% \text { treated } \\
\text { bamboo which is slightly higher than silane-treated } \\
\text { composite. }\end{array}$ & {$[74]$} \\
\hline 6 & Sisal & Alkaline treatment & Improvement in interfacial shear strength. & {$[75]$} \\
\hline 7 & Sisal/hemp & Alkaline treatment & $\begin{array}{l}\text { At } 10 \% \text { concentration of } \mathrm{NaOH} \text {, enhanced the flexural } \\
\text { strength by adding } 40 \mathrm{wt} \% \text { sisal and hemp. }\end{array}$ & {$[75]$} \\
\hline 8 & Curaua & Alkaline treatment & $\begin{array}{c}\text { An increase in } \mathrm{NaOH} \text { concentration and decrease of fiber } \\
\text { diameter, fiber density, and fiber weight. }\end{array}$ & {$[76]$} \\
\hline 9 & Ramie & Alkaline treatment & $\begin{array}{l}\text { Alkali treatment possesses better tensile strength than silane- } \\
\text { treated fiber composite. }\end{array}$ & {$[76]$} \\
\hline 10 & Hemp & Alkaline treatment & $\begin{array}{l}\text { The treated fiber has high crystallinity resulting in } \\
\text { improvement in tensile strength and Young's modulus. }\end{array}$ & {$[76]$} \\
\hline 11 & Jute & Alkaline treatment & $\begin{array}{l}\text { The treatment removed hemicellulose, pectin, and lignin } \\
\text { resulting in decreased fiber diameter. }\end{array}$ & {$[76]$} \\
\hline 12 & Basalt & Alkaline treatment & $\begin{array}{c}\text { The NaOH-treated fiber has superior properties compared to } \\
\text { glass fiber. }\end{array}$ & [76] \\
\hline 13 & Banana & Alkaline treatment & $5 \% \mathrm{NaOH}$-treated fiber has better properties. & {$[77]$} \\
\hline 14 & Luffa/coir & Alkaline treatment & $\begin{array}{l}\text { Improvement in tensile and flexural strength and hardness. } \\
\text { An increment in mechanical properties by removal of }\end{array}$ & {$[78]$} \\
\hline 15 & Luffa/groundnut fiber & Alkaline treatment & $\begin{array}{l}\text { hemicellulose, wax, lignin, and impurities from the fibers, } \\
\text { thus increasing the adhesive characteristics of composite. }\end{array}$ & [79] \\
\hline 16 & Abaca & Alkaline treatment & Improvement in moisture resistance. & {$[80]$} \\
\hline 17 & Alfa & Alkaline treatment & $\begin{array}{c}\text { At } 10 \% \text { of } \mathrm{NaOH} \text { content, increases in flexural strength and } \\
\text { flexural modulus by } 60 \% \text { and } 62 \% \text {, respectively, and fiber } \\
\text { becomes stiffer and brittle. }\end{array}$ & {$[81]$} \\
\hline 18 & $\begin{array}{l}\text { Drumstick (Moringa } \\
\text { oleifera) }\end{array}$ & Alkaline treatment & $\begin{array}{l}\text { The addition of glass fiber increased impact strength and } \\
\text { frictional coefficient. }\end{array}$ & {$[82]$} \\
\hline 19 & Ladies finger & Alkaline treatment & $\begin{array}{c}\text { Double-stage chemical treatment possessed better properties } \\
\text { than single-stage treatment, while an increase in span length } \\
\text { decreased the tensile strength and increased Young's } \\
\text { modulus. }\end{array}$ & {$[83]$} \\
\hline 20 & Tamarind & Alkaline treatment & $\begin{array}{l}\text { Chemically treated } 2 \mathrm{~cm} \text { fiber length was optimum to achieve } \\
\text { better hardness, impact, and frictional coefficient. }\end{array}$ & {$[84]$} \\
\hline 21 & $\begin{array}{l}\text { Vetiveria zizanioides/ } \\
\text { jute }\end{array}$ & Alkaline treatment & $\begin{array}{c}\text { The treated fibers improved tensile strength, flexural strength, } \\
\text { and impact strength by } 26.8 \%, 30.44 \% \text {, and } 59.1 \% \text {, } \\
\text { respectively. }\end{array}$ & {$[85]$} \\
\hline 22 & Borassus & Alkaline treatment & $\begin{array}{c}\text { At } 5 \% \text { of } \mathrm{NaOH} \text { content, significantly increased tensile } \\
\text { properties. }\end{array}$ & {$[86]$} \\
\hline 23 & Palm wood & Alkaline treatment & $\begin{array}{c}\text { The optimum residual mass at } 0 \% \text { to } 0.75 \% \mathrm{NaOH} \text {. With } \\
\text { further } 1 \% \mathrm{NaOH} \text { it decreased. }\end{array}$ & {$[87]$} \\
\hline 24 & $\begin{array}{l}\text { Palmyra palm leaf stalk } \\
\text { fiber (PPLSF)/jute }\end{array}$ & Alkaline treatment & $\begin{array}{l}\text { The alkali-treated PPLSF has maximum tensile and flexural } \\
\text { properties by the addition of alkali-treated jute fiber. }\end{array}$ & {$[88]$} \\
\hline 25 & Roystonea regia & Alkaline treatment & Improvement in tensile and flexural properties. & {$[88]$} \\
\hline 26 & $\begin{array}{l}\text { Borassus flabellifer } \\
\text { (Asian palmyra) }\end{array}$ & Alkaline treatment & Improvement in tensile strength. & {$[88]$} \\
\hline 27 & Buriti and ramie & Alkaline treatment & $\begin{array}{c}\text { At } 2 \% \mathrm{NaOH} \text { treatment of ramie fiber, increased flexural } \\
\text { strength by } 70 \% \text {. However, alkali treatment was only favorable } \\
\text { for buriti fibers. }\end{array}$ & [89] \\
\hline
\end{tabular}


TABle 1: Continued.

\begin{tabular}{|c|c|c|c|c|}
\hline $\begin{array}{l}\text { S. } \\
\text { no. }\end{array}$ & Fibers used & Type of chemical treatment & Effects & Ref. \\
\hline 28 & Rice husk & Alkaline treatment & $\begin{array}{l}\text { An increase in cellulose content, resulting in increased } \\
\text { crystallinity index. Therefore diameter decreased from } 170 \text { to } \\
7 \mathrm{~mm} \text {, as well as further diameter value from } 10 \text { to } 15 \mathrm{~nm} \text { by } \\
\text { performing acid hydrolysis treatment. }\end{array}$ & {$[90]$} \\
\hline 29 & Rice husk & Alkaline treatment & Improvement in adhesion characteristics. & {$[90]$} \\
\hline 30 & Jute & Alkaline treatment & $\begin{array}{c}\text { An increase in flexural strength, modulus, and interlaminar } \\
\text { shear strength. }\end{array}$ & {$[91]$} \\
\hline 31 & Coir & Alkaline treatment & $\begin{array}{c}\text { At } 5 \% \text { alkali treatment increases in impact and flexural } \\
\text { strength for } 72 \mathrm{~h} \text { by } 40 \% \text {. }\end{array}$ & {$[92]$} \\
\hline 32 & Jute & Alkaline treatment & $\begin{array}{l}\text { At } 5 \% \text { alkali treatment increases in flexural strength for } 4 \text { h by } \\
\qquad 20 \% .\end{array}$ & {$[93]$} \\
\hline 33 & Banana & Alkaline treatment & $\begin{array}{l}\text { At } 1 \% \text { alkali treatment enhanced flexural strength, flexural } \\
\text { modulus, tensile strength, and tensile modulus by } 20,12,132 \text {, } \\
\text { and } 131 \% \text {, respectively. }\end{array}$ & {$[94]$} \\
\hline 34 & Ramie & Alkaline treatment & $\begin{array}{l}\text { At } 9 \% \text { alkali treatment enhanced tensile strength for } 1 \mathrm{~h} \text { by } \\
\qquad 23 \% \text {. }\end{array}$ & {$[95]$} \\
\hline 35 & Jute & Alkaline treatment & $\begin{array}{c}\text { An increase in flexural strength, flexural modulus, and } \\
\text { interlaminar shear strength by } 35 \%, 23 \% \text {, and } 19 \% \text {, } \\
\text { respectively. }\end{array}$ & {$[93]$} \\
\hline 36 & Abaca/roselle & Alkaline treatment & $\begin{array}{l}\text { The treatment increased fiber/matrix adhesion property due } \\
\text { to removal of hemicellulose, waxes, lignin, and impurities } \\
\text { from the fibers. }\end{array}$ & {$[96]$} \\
\hline 37 & Jute & Alkaline treatment & $\begin{array}{l}\text { The treatment removed the hemicellulose and promoted the } \\
\text { interlocking points in the fiber for better adhesion and stress } \\
\text { transfer across the interface resulting in increased tensile } \\
\text { strength, flexural strength, flexural modulus, and interlaminar } \\
\text { shear strength. }\end{array}$ & {$[97]$} \\
\hline 38 & Jute & Alkaline treatment & $\begin{array}{l}\text { The treatment increased the cellulose content after removal of } \\
\text { pectin, lignin, and other impurities. An increase in cellulose } \\
\text { content leads to better interfacial adhesion. }\end{array}$ & {$[98]$} \\
\hline 39 & Sisal & Alkaline treatment & $\begin{array}{l}\text { The treatment had better mechanical properties due to good } \\
\text { adhesion between fiber and matrix. }\end{array}$ & [99] \\
\hline 40 & Oil palm & Alkaline treatment & $\begin{array}{l}\text { A bigger increase in flexural strength by performing } 24 \text {-hour } \\
\mathrm{NaOH} \text { treatments compared to other chemical treatments. } \\
\text { At } 25 \% \text { fiber loading and } 10 \% \mathrm{NaOH} \text { treatment showed }\end{array}$ & {$[100]$} \\
\hline 41 & Jute & Alkaline treatment & $\begin{array}{l}\text { increase in tensile strength due to decrease in fiber diameter } \\
\text { and density. }\end{array}$ & {$[101]$} \\
\hline 42 & Jute & Alkaline treatment & $\begin{array}{l}\text { At } 20 \% \text { fiber loading and } 10 \% \mathrm{NaOH} \text { treatment showed } \\
\text { increase in tensile strength due to decrease in fiber diameter } \\
\text { and density. }\end{array}$ & [102] \\
\hline 43 & Napier grass & Alkaline treatment & $\begin{array}{c}\text { The } 12 \mathrm{~h} \text { soaking time of treated fiber had least fiber diameter } \\
\text { and mass. The } 6 \mathrm{~h} \text { soaking time exhibited highest tensile } \\
\text { strength. An increase in surface roughness with the increase in } \\
\text { soaking time beyond } 18 \mathrm{~h} \text {. However, } 24 \mathrm{~h} \text {-treated fiber had } \\
\text { damage on its surface. }\end{array}$ & [103] \\
\hline 44 & Henequen & Alkaline treatment & $\begin{array}{l}\text { The treated fiber had higher adsorption rate at } 100 \mathrm{~h} \text { to attain } \\
\text { adsorption equilibrium. }\end{array}$ & {$[50]$} \\
\hline 45 & Sisal & Alkaline treatment & $\begin{array}{l}\text { The } 45 \text { min of treatment yielded more level of crystallinity } \\
\text { with more cell wall structure. Tensile and shear strength were } \\
\text { increased by } 12.04 \% \text { and } 173 \% \text {, respectively. }\end{array}$ & [104] \\
\hline 46 & Sisal & Alkaline treatment & $\begin{array}{l}\text { An increase in crystallinity decreased the absorption rate. } \\
\text { Optimum fiber length } 5.8-9 \mathrm{~cm} \text { displays better performance } \\
\text { in tensile strength with increase in fiber loading. }\end{array}$ & [105] \\
\hline 47 & Ladies finger & Alkaline treatment & $\begin{array}{c}\text { Removal of hydrophilic hemicellulose led to enhanced surface } \\
\text { roughness. }\end{array}$ & {$[83]$} \\
\hline 48 & Kenaf & Alkaline treatment & $\begin{array}{c}\text { Chemically treated } 6 \% \mathrm{NaOH} \text { sample was optimum to achieve } \\
\text { better tensile strength and modulus of elasticity. }\end{array}$ & [106] \\
\hline
\end{tabular}


TABLE 1: Continued.

\begin{tabular}{|c|c|c|c|c|}
\hline $\begin{array}{l}\text { S. } \\
\text { no. }\end{array}$ & Fibers used & Type of chemical treatment & Effects & Ref. \\
\hline 49 & Kenaf & Alkaline treatment & $\begin{array}{l}\text { At } 9 \% \mathrm{NaOH} \text { alkali treatment displayed cleanest surface } \\
\text { although tensile strength decreased. However, } 6 \% \mathrm{NaOH} \\
\text { alkali treatment with higher temperature was optimum in } \\
\text { cleaning fiber. }\end{array}$ & [49] \\
\hline 50 & Banana & Alkaline treatment & $\begin{array}{l}\text { An enhancement in tensile modulus and impact and tensile } \\
\text { strength by adding } 3 \mathrm{wt} \% \text { of fiber. }\end{array}$ & [107] \\
\hline 51 & Banana & Alkaline treatment & $\begin{array}{c}\text { At } 10 \% \text { of } \mathrm{NaOH} \text { content, significantly increased thermal } \\
\text { conductivity. }\end{array}$ & [108] \\
\hline 52 & Banana & Alkaline treatment & $\begin{array}{l}\text { At } 4 \% \text { concentration of } \mathrm{NaOH} \text {, enhanced the tensile strength, } \\
\text { tensile modulus, and flexural strength. }\end{array}$ & [109] \\
\hline 53 & Banana & Alkaline treatment & $\begin{array}{l}\text { Alkali treatment possesses better tensile strength and flexural } \\
\text { strength when compared with benzoylation and PSMA } \\
\text { treatment. }\end{array}$ & {$[110]$} \\
\hline 54 & Banana & Alkaline treatment & $\begin{array}{l}\text { The treatment decreased modulus of rigidity, tensile strength, } \\
\text { and strain due to degradation of cellulose. }\end{array}$ & [111] \\
\hline 55 & Pineapple leaf & Alkaline treatment & $\begin{array}{l}\text { An increase in fiber density, cellulose, and crystallinity led to } \\
\text { enhanced tensile strength, thermal stability, and water } \\
\text { retention with increasing the } \mathrm{NaOH} \text { up to } 7 \% \text { concentration. } \\
\text { The treated fiber significantly improved the flexural strength, } \\
\text { impact strength, storage modulus, and thermal resistance by }\end{array}$ & [112] \\
\hline 56 & Pineapple leaf & Alkaline treatment & $\begin{array}{l}79 \% \text {. Heat deflection temperature }\left(171.3^{\circ} \mathrm{C}\right) \text { which is close to } \\
\text { the melting temperature of neat polymer. Reduction in } \\
\text { crystallization by } 14^{\circ} \mathrm{C} \text {. }\end{array}$ & [113] \\
\hline 57 & Pineapple leaf & Alkaline treatment & $\begin{array}{c}\text { An enhancement in Young's modulus by } 30 \% \text { compared to } \\
\text { untreated fiber. }\end{array}$ & {$[114]$} \\
\hline 58 & WSF & Alkaline treatment & An enhancement in thermal stability by adding $3 \% \mathrm{NaOH}$. & [115] \\
\hline 59 & Banana & Alkaline treatment & At $1 \% \mathrm{NaOH}$ treatment possess better properties. & {$[94]$} \\
\hline 60 & Hemp & $5 \% \mathrm{NaOH}, 0.5 \%$ silane & $\begin{array}{c}\text { The combined } \mathrm{NaOH} \text { and silane treatment increased the } \\
\text { tensile and flexural strength by } 100 \% \text { and } 45 \% \text {, respectively. } \\
\text { But fracture toughness decreased. }\end{array}$ & [116] \\
\hline 61 & Jute & Alkaline treatment & At $4 \% \mathrm{NaOH}$ treatment increased tensile strength up to $30 \%$. & {$[117]$} \\
\hline 62 & Agave & Alkaline treatment & Increased the fiber matrix adhesion and fracture strain. & [118] \\
\hline 63 & Palm leaf stalk/jute & Alkaline treatment & $\begin{array}{c}\text { An increase in storage modulus and loss modulus by addition } \\
\text { of jute fiber. }\end{array}$ & {$[88]$} \\
\hline 64 & Coir & Alkaline treatment & $\begin{array}{c}\text { Enhancement in mechanical properties, moisture resistance, } \\
\text { and adhesion properties. }\end{array}$ & [119] \\
\hline 65 & Flax & $\begin{array}{l}\text { Benzoylation, peroxide, } \\
\text { mercerization, silane } \\
\text { treatment. }\end{array}$ & $\begin{array}{c}\text { The treatment exhibited improved mechanical and physical } \\
\text { properties. }\end{array}$ & [120] \\
\hline 66 & Hemp/jute & Alkaline treatment & $\begin{array}{l}\text { Increase in crystallinity can enhance the fiber strength. } \\
\text { An increase in crystallinity of PLA matrix due to crystalline }\end{array}$ & {$[121-123]$} \\
\hline 67 & Hemp & Alkaline treatment & $\begin{array}{l}\text { cellulose in the alkaline-treated hemp fibers, which acts } \\
\text { nucleating sites resulting in increase in fiber strength. }\end{array}$ & {$[124]$} \\
\hline 68 & Kenaf/hemp & Alkaline treatment & $\begin{array}{l}\text { The treated fiber found to have better mechanical properties, } \\
\text { thermal stability, and moisture resistance. }\end{array}$ & {$[125,126]$} \\
\hline 69 & Sisal & Combined $\mathrm{NaOH}+$ actylation & $\begin{array}{c}\text { Increase in mechanical properties due to better adhesion } \\
\text { between fiber and matrix. }\end{array}$ & {$[104]$} \\
\hline 70 & Tridax procumbens & Alkaline treatment & $\begin{array}{l}\text { At } 5 \% \text { concentration of } \mathrm{NaOH} \text {, enhanced the wettability and } \\
\text { crystallinity and reduced amorphous region and fiber } \\
\text { diameter. }\end{array}$ & [127] \\
\hline
\end{tabular}

Figure 2 represents the SEM images of untreated and treated Prosopis juliflora fiber-reinforced epoxy composites at different concentrations $(5 \%, 10 \%$, and $15 \%)$. Figure $2(a)$ shows the untreated fiber surface which consists of impurities and fiber pull-outs on the surface. This was due to the waxy substances present on the surface of the fiber and the existence of hydroxyl groups, which leads to water absorption, weakening interfacial strength with the matrix.
Figures 2(b)-2(d) represent the treated Prosopis juliflora fiber-reinforced epoxy composites at concentrations of 5\%, $10 \%$, and $15 \%$, and increase in alkali treatment beyond $5 \%$ damaged the fiber surface and reduced the cellulose content in the fiber, which in turn resulted in lower strength and stiffness [175].

Liu et al. [176] researched the supremacy of silane coupling agent treatment done on the surface of corn stalk 
TABLE 2: Effect of silane treatment on various biofibers.

\begin{tabular}{|c|c|c|c|c|}
\hline $\begin{array}{l}\text { S. } \\
\text { no. }\end{array}$ & Fibers used & $\begin{array}{l}\text { Type of chemical } \\
\text { treatment }\end{array}$ & Effects & Ref. \\
\hline 1 & Kenaf & Silane treatment & $\begin{array}{l}\text { The presence of lignin and hemicellulose was removed by performing silane } \\
\text { treatment. Removal of lignin and hemicellulose led to enhanced interfacial } \\
\text { bonding. }\end{array}$ & [71] \\
\hline 2 & $\begin{array}{l}\text { Pineapple } \\
\text { leaf }\end{array}$ & Silane treatment & $\begin{array}{l}\text { The treated fiber has fewer voids on the interface which makes strong } \\
\text { interfacial bonding and results in better mechanical properties. }\end{array}$ & {$[71]$} \\
\hline 3 & Abaca & $\begin{array}{l}\text { Mercerization and silane } \\
\text { treatment }\end{array}$ & The silane-treated fiber has higher thermal transfer coefficient. & {$[73]$} \\
\hline 4 & Bamboo & Silane treatment & $\begin{array}{l}\text { An enhancement in tensile strength by incorporation of } 30 \% \text { treated bamboo, } \\
\text { while flexural strength is higher than that of } \mathrm{NaOH} \text {-treated fiber. }\end{array}$ & {$[74]$} \\
\hline 5 & Sisal & Silane treatment & The treatment enhances the mechanical properties and moisture resistance. & {$[75]$} \\
\hline 6 & $\begin{array}{l}\text { Hemp/ } \\
\text { kenaf }\end{array}$ & Silane treatment & $\begin{array}{l}\text { The treatment possesses higher flexural modulus in comparison with alkali- } \\
\text { treated composite and similar to glass fiber composite. }\end{array}$ & {$[128]$} \\
\hline 7 & Hemp & Silane treatment & Flexural and tensile strength were increased by $2 \%$ and $4 \%$, respectively. & {$[129]$} \\
\hline 8 & Kenaf & Silane treatment & $\begin{array}{c}\text { An enhancement in storage modulus and viscoelasticity by } 45 \% \text { and } 25 \% \text {, } \\
\text { respectively. }\end{array}$ & {$[130]$} \\
\hline 9 & Oil palm & Silane treatment & $\begin{array}{c}\text { Reduced the mechanical properties due to poor adhesion between fiber and } \\
\text { matrix. }\end{array}$ & {$[131]$} \\
\hline 10 & Henequen & Silane treatment & $\begin{array}{c}\text { An enhancement in tensile strength from } 21 \mathrm{MPa} \text { to } 27 \mathrm{MPa} \text { by performing } \\
\text { combination of silane and } \mathrm{NaOH} \text {. }\end{array}$ & {$[50]$} \\
\hline 11 & Sisal & Silane treatment & The treated fiber had higher impact strength compared to alkali-treated fibers. & {$[132]$} \\
\hline 12 & Banana & Silane treatment & $\begin{array}{c}\text { An increase in flexural strength about } 160 \% \text { and considerable increase in } \\
\text { tensile and toughness. }\end{array}$ & {$[133]$} \\
\hline 13 & Banana & Silane treatment & $\begin{array}{l}\text { An enhancement in impact and tensile strength by } 30.84 \% \text { and } 19.43 \% \text {, } \\
\text { respectively, and slight increase in tensile modulus. }\end{array}$ & {$[134]$} \\
\hline 14 & Jute & Silane treatment & $\begin{array}{c}\text { An increase in strength and modulus about } 12 \% \text { and } 7 \% \text { by alkali treatment } \\
\text { followed by silane treatment. }\end{array}$ & [135] \\
\hline 15 & Jute & Silane treatment & $\begin{array}{l}\text { At } 0.3 \% \text {, silane-treated composites enhanced the tensile, flexural, and } \\
\text { interlaminar shear strength by } 40 \%, 30 \% \text {, and } 55 \% \text {, respectively. }\end{array}$ & [113] \\
\hline 16 & $\begin{array}{l}\text { Pineapple } \\
\text { leaf }\end{array}$ & Silane treatment & $\begin{array}{l}\text { Improvement in flexural modulus and storage modulus by } 47 \% \text { as compared to } \\
\text { alkali treatment. }\end{array}$ & [114] \\
\hline 17 & $\begin{array}{l}\text { Pineapple } \\
\text { leaf }\end{array}$ & Silane treatment & $\begin{array}{l}\text { The resulting composite has less Young's modulus than alkali-treated } \\
\text { composites. }\end{array}$ & {$[136]$} \\
\hline 18 & $\begin{array}{l}\text { Pineapple } \\
\text { leaf }\end{array}$ & Silane treatment & $\begin{array}{l}\text { Reduction of hydrophilic tendency of the fibers leads to increase in tensile } \\
\text { strength and crystallinity size but } \% \text { crystallinity decreases. }\end{array}$ & {$[72]$} \\
\hline 19 & Hemp & Silane treatment & $\begin{array}{l}\text { Found maximum mechanical properties compared to other chemical } \\
\text { treatments. }\end{array}$ & [137-139] \\
\hline
\end{tabular}

TABLE 3: Effect of acetylation treatment on various biofibers.

\begin{tabular}{|c|c|c|c|c|}
\hline $\begin{array}{l}\text { S. } \\
\text { no. }\end{array}$ & Fibers used & $\begin{array}{l}\text { Type of chemical } \\
\text { treatment }\end{array}$ & Effects & Ref. \\
\hline 1 & Coir/oil palm & $\begin{array}{l}\text { Acetylation } \\
\text { treatment }\end{array}$ & $\begin{array}{l}\text { A bigger increase in tensile strength, flexural strength, Young's modulus, and } \\
\text { impact strength by performing acetylation treatment compared to silane } \\
\text { treatment. }\end{array}$ & [140] \\
\hline 2 & Flax & $\begin{array}{l}\text { Acetylation } \\
\text { treatment }\end{array}$ & An enhancement in tensile and flexural strength by $35 \%$. & [141] \\
\hline 3 & Abaca & $\begin{array}{l}\text { Acetylation } \\
\text { treatment }\end{array}$ & $\begin{array}{l}\text { The treatment possessed higher tensile strength, Young's modulus, and impact } \\
\text { strength by } 81,70 \text {, and } 8 \% \text {, respectively. }\end{array}$ & [133] \\
\hline 4 & Oil palm & $\begin{array}{l}\text { Acetylation } \\
\text { treatment }\end{array}$ & $\begin{array}{c}\text { The treatment has high strain value which resulted in enhanced elastic and } \\
\text { impact property. }\end{array}$ & [100] \\
\hline 5 & Green flax & $\begin{array}{l}\text { Acetylation } \\
\text { treatment }\end{array}$ & $\begin{array}{l}\text { At } 65 \% \text { of relative humidity, decrease in the moisture absorption. An increase in } \\
\text { thermal stability with increase in degree of acetylation. About } 25 \% \text { improvement } \\
\text { in strength properties was observed compared to untreated composites. }\end{array}$ & [139] \\
\hline 6 & Flax & $\begin{array}{l}\text { Acetylation } \\
\text { treatment }\end{array}$ & $\begin{array}{l}\text { At } 18 \% \text { of acetylation, concentration of flax fiber exhibited better tensile } \\
\text { strength and thermal stability by } 25 \% \text { and } 50 \% \text {, respectively. However, the } \\
\text { addition of maleic anhydride resulted in increase in mechanical properties by } \\
20-35 \% \text {. }\end{array}$ & [139] \\
\hline
\end{tabular}


TABle 3: Continued.

\begin{tabular}{|c|c|c|c|c|}
\hline $\begin{array}{l}\text { S. } \\
\text { no. }\end{array}$ & Fibers used & $\begin{array}{c}\text { Type of chemical } \\
\text { treatment }\end{array}$ & Effects & Ref. \\
\hline 7 & Sisal & $\begin{array}{l}\text { Acetylation } \\
\text { treatment }\end{array}$ & $\begin{array}{l}\text { Improvement in tensile strength and shear strength by } 14.08 \% \text { and } 435 \% \text {, } \\
\text { respectively. The acetic acid treatment followed by ethyl acetate with } \mathrm{H}_{2} \mathrm{SO}_{4} \\
\text { resulted in high levels of cellulose swelling or loosened cell wall structure. }\end{array}$ & [104] \\
\hline 8 & Sisal & $\begin{array}{l}\text { Acetylation } \\
\text { treatment }\end{array}$ & A decrease in dielectric constant with increasing frequency. & [105] \\
\hline 9 & Banana & $\begin{array}{c}\text { Acetylation } \\
\text { treatment }\end{array}$ & $\begin{array}{l}\text { The treated fiber has high fibrillation and is more rougher resulting in better } \\
\text { tensile properties than mercerization treatment. }\end{array}$ & [109] \\
\hline 10 & Grewia serrulata bast & $\begin{array}{c}\text { Acetylation } \\
\text { treatment }\end{array}$ & $\begin{array}{l}\text { The treated fiber has better dimensional stability and more moisture resistance. } \\
\text { However, high degree of ultraviolent energy can degrade the composite. }\end{array}$ & [142] \\
\hline 11 & $\begin{array}{l}\text { Phosphate bonded } \\
\text { composite }\end{array}$ & $\begin{array}{l}\text { Acetylation } \\
\text { treatment }\end{array}$ & $\begin{array}{l}\text { The treated fiber reduces water absorption and hence improves dimensional } \\
\text { stability, tensile strength, and stiffness. However, this treatment reduces the } \\
\text { impact strength as compared to other chemical treatments. }\end{array}$ & [143] \\
\hline
\end{tabular}

TABLE 4: Effect of permanganate $\left(\mathrm{KMnO}_{4}\right)$ treatment on various biofibers.

\begin{tabular}{|c|c|c|c|c|}
\hline $\begin{array}{l}\text { S. } \\
\text { no. }\end{array}$ & $\begin{array}{c}\text { Fibers } \\
\text { used }\end{array}$ & $\begin{array}{l}\text { Type of chemical } \\
\text { treatment }\end{array}$ & Effects & Ref. \\
\hline 1 & Sisal & $\begin{array}{l}\text { Permanganate } \\
\text { treatment }\end{array}$ & Improvement in tensile strength. & {$[75]$} \\
\hline 2 & Oil palm & $\begin{array}{l}\text { Permanganate } \\
\text { treatment }\end{array}$ & $\begin{array}{l}\text { The treated fiber has highly fibrillated structure and hence very good fiber matrix } \\
\text { adhesion. As a result, better tensile strength and modulus were observed }\end{array}$ & [100] \\
\hline 3 & Sisal & $\begin{array}{l}\text { Permanganate } \\
\text { treatment }\end{array}$ & $\begin{array}{l}\text { At } 1 \% \text { concentration of } \mathrm{KMnO}_{4} \text { polar groups between fiber and matrix are formed } \\
\text { leading to degradation of cellulose. The hydrophilic tendency of fiber decreases as the } \\
\qquad \mathrm{KMnO}_{4} \text { concentration increases up to an optimum. }\end{array}$ & [105] \\
\hline 4 & Sisal & $\begin{array}{l}\text { Permanganate } \\
\text { treatment }\end{array}$ & $\begin{array}{l}\text { At } 1 \% \text { concentration, higher degradation of cellulose occurred due to formation of polar } \\
\text { group. Optimum properties were found to be better at } 0.055 \% \text { concentration. Tensile } \\
\text { properties were observed between alkali and peroxide. }\end{array}$ & [144] \\
\hline 5 & Sisal & $\begin{array}{l}\text { Permanganate } \\
\text { treatment }\end{array}$ & $\begin{array}{l}\text { Improvement in interlaminar shear strength, tensile strength, and flexural properties } \\
\text { compared to silane. But impact properties were lower than those of untreated fiber. }\end{array}$ & [145] \\
\hline 6 & Banana & $\begin{array}{l}\text { Permanganate } \\
\text { treatment }\end{array}$ & $\begin{array}{c}\text { An increase in thermal diffusivity, tensile strength, and tensile modulus by } 16 \%, 6.4 \% \text {, } \\
\text { and } 7.5 \% \text {, respectively. However, flexural strength and modulus were found to have } \\
\text { increases of } 6 \% \text { and } 10 \% \text {, respectively, which were lower compared to alkali and silane } \\
\text { treatment. }\end{array}$ & [108] \\
\hline 7 & Flax & $\begin{array}{l}\text { Permanganate } \\
\text { treatment }\end{array}$ & $\begin{array}{c}\text { Improvement in tensile and moisture resistance as compared to alkali and silane-treated } \\
\text { fibers. }\end{array}$ & [108] \\
\hline 8 & Banana & $\begin{array}{l}\text { Permanganate } \\
\text { treatment }\end{array}$ & $\begin{array}{l}\text { An increase in tensile strength and flexural strength by } 5 \% \text { and } 10 \% \text {, respectively. } \\
\text { Increases in polarity and roughness of fiber were also observed. }\end{array}$ & [146] \\
\hline
\end{tabular}

TABle 5: Effect of peroxide treatment on various biofibers.

\begin{tabular}{|c|c|c|c|c|}
\hline $\begin{array}{l}\text { S. } \\
\text { no. }\end{array}$ & Fibers used & $\begin{array}{c}\text { Type of chemical } \\
\text { treatment }\end{array}$ & Effects & Ref. \\
\hline 1 & Sisal & Peroxide treatment & Enhancement in tensile properties. & [72] \\
\hline 2 & Sisal & Peroxide treatment & $\begin{array}{l}\text { Crystallinity index and decomposition rate were found to be better at soaking time of } \\
\qquad 30 \mathrm{~min} \text {. }\end{array}$ & [146] \\
\hline 3 & Kenaf & Peroxide treatment & $\begin{array}{c}\text { At } 30 \% \text { fiber loading exhibited higher tensile and flexural strength, whereas modulus was } \\
\text { high at } 40 \% \text { fiber loading. }\end{array}$ & [146] \\
\hline 4 & Oil palm & Perox & Improvement in flexural modulus as compared to other chemical treatments. & [147] \\
\hline 5 & Sisal & Peroxide treatment & $\begin{array}{l}50 \% \text { higher tensile strength of treated fiber compared to } \\
\text { The treatment exhibited better tensile and flexural } \mathrm{p}\end{array}$ & [105] \\
\hline 6 & Jute & Peroxide treatment & $\begin{array}{l}\text { permanganate treatment, but not as superior as silane treatment, whereas the thermal } \\
\text { stability was reduced. }\end{array}$ & [105] \\
\hline 7 & $\begin{array}{l}\text { Pineapple } \\
\text { leaf }\end{array}$ & Peroxide treatment & $\begin{array}{l}\text { Better in tensile strength, tensile modulus, and abrasion resistance as compared to } \\
\text { untreated composites. But there was a reduction in elongation breaks. }\end{array}$ & [148] \\
\hline 8 & Wheat straw & Peroxide treatment & $\begin{array}{l}\text { The treated composites were found to have increase in ash content. Removal of lignin } \\
\text { was around } 50 \% .\end{array}$ & [149] \\
\hline
\end{tabular}


TABLE 6: Effect of benzoylation treatment on various biofibers.

\begin{tabular}{|c|c|c|c|c|}
\hline $\begin{array}{l}\text { S. } \\
\text { no. }\end{array}$ & $\begin{array}{c}\text { Fibers } \\
\text { used }\end{array}$ & $\begin{array}{l}\text { Type of chemical } \\
\text { treatment }\end{array}$ & Effects & Ref. \\
\hline 1 & Sisal & $\begin{array}{l}\text { Benzoylation } \\
\text { treatment }\end{array}$ & Improvement in tensile strength by $91 \%$. & [75] \\
\hline 2 & Jute & $\begin{array}{l}\text { Benzoylation } \\
\text { treatment }\end{array}$ & Improvement in storage modulus and thermal stability. & {$[150]$} \\
\hline 3 & Flax & $\begin{array}{l}\text { Benzoylation } \\
\text { treatment }\end{array}$ & $\begin{array}{l}\text { The treated composites were found to have highest tensile and impact strength for LDPE } \\
\text { and highest impact strength for HDPE. Resulted in less water absorption as compared to } \\
\text { silane and peroxide. Smooth fiber surface was observed. }\end{array}$ & {$[43]$} \\
\hline 4 & Sisal & $\begin{array}{l}\text { Benzoylation } \\
\text { treatment }\end{array}$ & At $6 \%$ of benzoyl peroxide showed better mechanical properties. & {$[83]$} \\
\hline 5 & Banana & $\begin{array}{l}\text { Benzoylation } \\
\text { treatment }\end{array}$ & $\begin{array}{l}\text { The treatment significantly improved thermal conductivity and was found to have } \\
\text { increase in tensile strength and modulus by } 13 \% \text { and } 5 \% \text {, respectively, although not as } \\
\text { good as alkali and silane-treated fiber. }\end{array}$ & [109] \\
\hline 6 & Sisal & $\begin{array}{l}\text { Benzoylation } \\
\text { treatment }\end{array}$ & $\begin{array}{l}\text { The treatment increased the activation energy for glass transition temperature ( } \mathrm{Tg}) \text {. } \\
\text { Maximum activation energy was observed. }\end{array}$ & {$[151]$} \\
\hline
\end{tabular}

TABLE 7: Effect of acrylation treatment on various biofibers.

\begin{tabular}{|c|c|c|c|c|}
\hline $\begin{array}{l}\text { S. } \\
\text { no. }\end{array}$ & $\begin{array}{c}\text { Fibers } \\
\text { used }\end{array}$ & $\begin{array}{l}\text { Type of chemical } \\
\text { treatment }\end{array}$ & Effects & Ref. \\
\hline 1 & Bagasse & $\begin{array}{l}\text { Acrylation } \\
\text { treatment }\end{array}$ & $\begin{array}{c}\text { Acrylation treatment offers superior tensile and flexural strength compared to alkali } \\
\text { treatment. }\end{array}$ & {$[152]$} \\
\hline 2 & Oil palm & $\begin{array}{l}\text { Acrylation } \\
\text { treatment }\end{array}$ & $\begin{array}{l}\text { The treatment yielded higher extension and impact resistance. At } 40 \% \text { of fiber with } \\
50^{\circ} \mathrm{C} \text { exhibited moderate level of moisture absorption compared to other treatments. }\end{array}$ & {$[102,155]$} \\
\hline 3 & Flax & $\begin{array}{l}\text { Acrylation } \\
\text { treatment }\end{array}$ & $\begin{array}{l}\text { The treated fiber exhibited higher tensile strength and moisture resistance than those } \\
\text { treated with silane, permanganate, and sodium chloride treatment. Higher smooth } \\
\text { fiber surface was observed. }\end{array}$ & [131] \\
\hline 4 & Flax & $\begin{array}{l}\text { Acrylation } \\
\text { treatment }\end{array}$ & $\begin{array}{l}\text { At higher concentration, grafting was increased due to higher availability of monomer } \\
\text { molecules in cellulose radicals as well as polymerization medium. }\end{array}$ & [154] \\
\hline 5 & Jute & $\begin{array}{l}\text { Acrylation } \\
\text { treatment }\end{array}$ & An increase in tensile strength and flexural strength by $42.2 \%$ and $13.9 \%$, respectively. & [155] \\
\hline
\end{tabular}

TABLE 8: Effect of acrylonitrile grafting treatment on various biofibers.

\begin{tabular}{|c|c|c|c|c|}
\hline $\begin{array}{l}\text { S. } \\
\text { no. }\end{array}$ & Fibers used & $\begin{array}{l}\text { Type of chemical } \\
\text { treatment }\end{array}$ & Effects & Ref. \\
\hline 1 & Pineapple leaf & Acrylonitrile grafting & $\begin{array}{c}\text { Improvement in tensile strength by adding AN (acrylonitrile grafting). It has } \\
\text { major effect on tensile strength. }\end{array}$ & {$[75,102]$} \\
\hline 2 & Oil palm & Acrylonitrile grafting & $\begin{array}{l}\text { The treatment showed high strain rate and elastic modulus. But slight } \\
\text { improvement in stiffness was absorbed. However at } 40 \mathrm{wt} \% \text { of fiber with } 50^{\circ} \mathrm{C} \\
\text { exhibited higher moisture resistance compared to other treatments. }\end{array}$ & [153] \\
\hline 3 & $\begin{array}{l}\text { Agave Americana } \\
\text { fibers }\end{array}$ & Acrylonitrile grafting & $\begin{array}{l}\text { An increase in percentage of graft and decrease in the moisture resistance, in } \\
\text { addition to improvement in thermal stability of fiber. }\end{array}$ & [156] \\
\hline 4 & Sisal & Acrylonitrile grafting & $\begin{array}{l}\text { The treatment showed enhanced tensile and flexural strength as compared to } \\
\text { other treatments. Least degradability of fibers was observed. }\end{array}$ & [157] \\
\hline 5 & Pineapple leaf & Acrylonitrile grafting & The treatment possesses lower grafting yield than unmodified fibers. & {$[158]$} \\
\hline 6 & Cellulose polymer & $\begin{array}{c}\text { Graft } \\
\text { copolymerization }\end{array}$ & Improvement in physical, chemical, and thermal resistance. & [159] \\
\hline
\end{tabular}

fibers extracted from the waste of corn stalk. Initially the fibers were modified with different percentages of silane concentration such as $1 \%, 5 \%, 9 \%$, and $13 \%$. The effect of silane treatment on corn stalk fibers was investigated by FTIR and XRD analysis. Results showed improvement in the crystalline size for $5 \%$ silane-treated fiber and also removal of hemicellulose, lignin, and other impurities present in the fibers was found by FTIR analysis. The impact behaviour of the composites was also found to be superior for $5 \%$ silanetreated corn stalk fiber-reinforced composites. Finally SEM analysis revealed that the surface of fibers was rough in contrast with untreated fiber owing to the effect of silane treatment. Liu et al. [177] investigated the effect of silane coupling agent on the mechanical, tribological, and morphological characteristics of corn stalk fiber-reinforced polymer composites. The extracted corn stalk fibers were 
TABLE 9: Effect of isocyanate treatment on various biofibers.

\begin{tabular}{|c|c|c|c|c|}
\hline $\begin{array}{l}\text { S. } \\
\text { no. }\end{array}$ & Fibers used & $\begin{array}{l}\text { Type of chemical } \\
\text { treatment }\end{array}$ & Effects & Ref. \\
\hline 1 & Oil palm & $\begin{array}{c}\text { Isocyanate } \\
\text { treatment }\end{array}$ & $\begin{array}{c}\text { At } 40 \% \text { fiber loading exhibited higher moisture absorption (280\%) compared to } \\
\text { other treatments. }\end{array}$ & [153] \\
\hline 2 & Sisal & $\begin{array}{l}\text { Isocyanate } \\
\text { treatment }\end{array}$ & $\begin{array}{l}\text { The treatment exhibited superior tensile properties than alkaline and untreated } \\
\text { fibers but with decrease in dielectric constant. }\end{array}$ & {$[107,146]$} \\
\hline 3 & Pineapple leaf & $\begin{array}{l}\text { Isocyanate } \\
\text { treatment }\end{array}$ & $\begin{array}{c}\text { The treatment reduced hydrophilic tendency of the fiber compared to silane- } \\
\text { treated composites. Reduction in \% of crystallinity leads to increase in tensile } \\
\text { strength. }\end{array}$ & [136] \\
\hline 4 & $\begin{array}{l}\text { Jute/hemp/ } \\
\quad \text { flax }\end{array}$ & $\begin{array}{l}\text { Isocyanate } \\
\text { treatment }\end{array}$ & The treatment increased stiffness and reduction in impact by $17 \%$. & {$[31]$} \\
\hline 5 & $\begin{array}{l}\text { Fibrous } \\
\text { cellulose }\end{array}$ & $\begin{array}{l}\text { Isocyanate } \\
\text { treatment }\end{array}$ & The treatment shows enhanced tensile, elongation, and interfacial adhesion. & {$[160]$} \\
\hline 6 & Kenaf & $\begin{array}{l}\text { Isocyanate } \\
\text { treatment }\end{array}$ & $\begin{array}{l}\text { The presence of isocyanate hydrolysis to urea, reacting with hydroxyl group of } \\
\text { fiber, decreases the moisture absorption and increases the mechanical properties. }\end{array}$ & {$[72]$} \\
\hline 7 & Sisal & $\begin{array}{l}\text { Isocyanate } \\
\text { treatment }\end{array}$ & Improvement in tensile strength & [161] \\
\hline
\end{tabular}

TABLE 10: Effect of maleic anhydride grafted treatment on various biofibers.

\begin{tabular}{|c|c|c|c|c|}
\hline $\begin{array}{l}\text { S. } \\
\text { no. }\end{array}$ & Fibers used & Type of chemical treatment & Effects & Ref. \\
\hline 1 & Jute & Maleic anhydride grafted & $\begin{array}{c}\text { Coupling agent has greater effect on Young's modulus and dynamic } \\
\text { storage modulus. }\end{array}$ & [162] \\
\hline 2 & Flax and hemp & Maleic anhydride grafted & The treatment improved dynamic and mechanical properties. & {$[163]$} \\
\hline 3 & WSF & Maleic anhydride grafted & $\begin{array}{l}\text { The treatment significantly reduced crystallinity and thermal stability is } \\
\text { higher than that in acetylation treatment. }\end{array}$ & [164] \\
\hline 4 & Wood flour & Maleic anhydride grafted & $\begin{array}{l}\text { An enhancement in tensile strength and modulus properties became twice } \\
\text { as compared with untreated fibers. }\end{array}$ & {$[165]$} \\
\hline 5 & Sisal & Maleic anhydride grafted & $\begin{array}{l}\text { Improvement in tensile, flexural, and impact strength by } 50 \%, 30 \% \text {, and } \\
58 \% \text {, respectively. Reduction in water absorption by } 61 \% \text {. Higher level of } \\
\text { crystallinity was also observed. }\end{array}$ & [166] \\
\hline 6 & $\begin{array}{l}\text { Banana/hemp/ } \\
\text { sisal }\end{array}$ & Maleic anhydride grafted & $\begin{array}{l}\text { Reduction in moisture resistance compared to untreated fiber. At } 50 \% \\
\text { fiber loading, increases in tensile, flexural, and impact strength. Flexural } \\
\text { modulus values were higher than those of untreated fiber. }\end{array}$ & [167] \\
\hline 7 & Hildegardia & Maleic anhydride grafted & $\begin{array}{l}\text { An increase in tensile properties with addition of compatibilizers. } \\
\text { The treated fiber exhibited increased aspect ratio and matrix resulting in }\end{array}$ & [168] \\
\hline 8 & Pineapple leaf & Maleic anhydride grafted & $\begin{array}{l}\text { increased tensile strength, impact strength, and flexural strength by } 9 \% \text {, } \\
30 \% \text {, and } 3 \% \text {, respectively, compared to untreated fibers }\end{array}$ & [169] \\
\hline 9 & Jute/sisal & $\begin{array}{l}\text { Maleic anhydride grafted } \\
\text { maleated HDPE }\end{array}$ & $\begin{array}{l}\text { At } 1 \% \text { concentration of coupling agent increased the dynamic (storage } \\
\text { modulus and loss modulus) and static (tensile, flexural, and impact) } \\
\text { mechanical properties. }\end{array}$ & {$[170,171]$} \\
\hline 10 & Wood flour & Maleated polypropylene & $\begin{array}{c}\text { An increase in dimensional stability and strengthening by MAPP } \\
\text { addition. }\end{array}$ & {$[172]$} \\
\hline 11 & Natural fibers & Maleated coupling agents & $\begin{array}{l}\text { An increase in interfacial adhesion between fiber and matrix due to } \\
\text { removal of hydroxyl group by addition of coupling agent. }\end{array}$ & [173] \\
\hline
\end{tabular}

exposed to surface modifications with silane coupling agents. Results showed an enhancement in water absorption and porosity of the silane-treated corn stalk fiber-reinforced composite specimens. Improvement in wear behaviour was noticed between the untreated and silane-treated corn stalk fiber-reinforced polymer composites. SEM analysis revealed the formation of secondary plateaus on the composite specimens which leads to the reduced wear rate on the composite samples. Jappes and Siva [178] researched the influence of silane modification done after the mercerization treatment on coconut sheath fiber to improvise the mechanical properties of the composites. The fabricated coconut sheath polyester composites were taken for testing of tensile, flexural, and impact strength, and the properties were compared with fabricated glass fiber-reinforced polyester composites. The coconut sheath fiber-reinforced composites showed better mechanical properties against glass fiber-reinforced polyester composites. The alkali and silane modification done on the surface of coconut sheath improved the hydrophilic nature of the fiber which ensured enhanced adhesion between the coconut sheath fibril and the matrix. SEM analysis was done to study the result of alkalization on the coconut sheath fiber; dismissal of waxy layers and other surface related impurities to make the fiber 


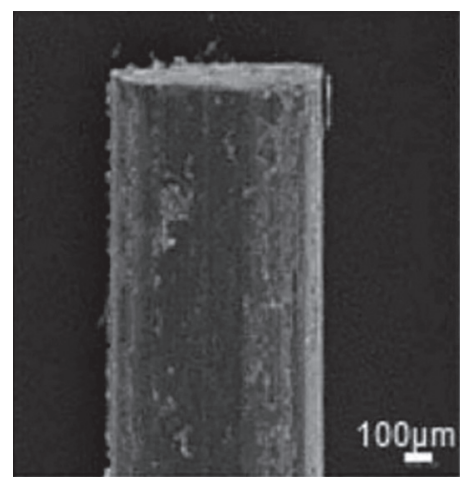

(a)

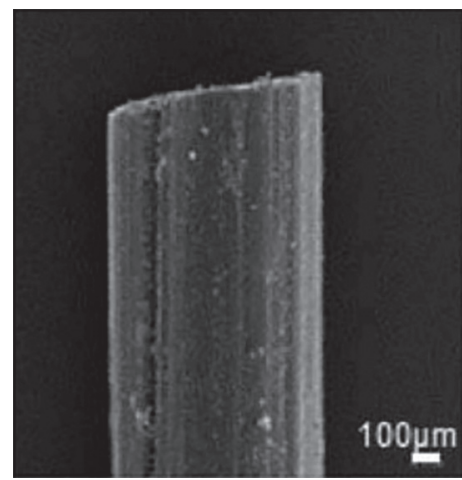

(d)

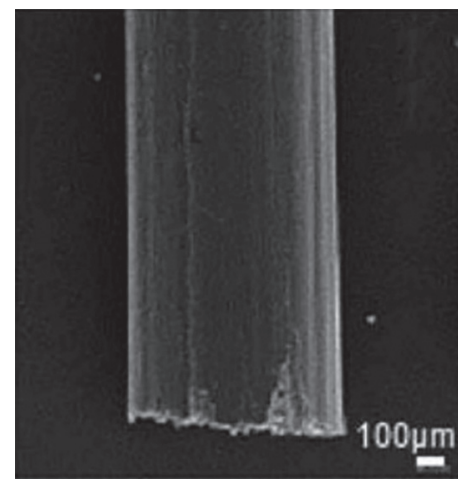

(b)

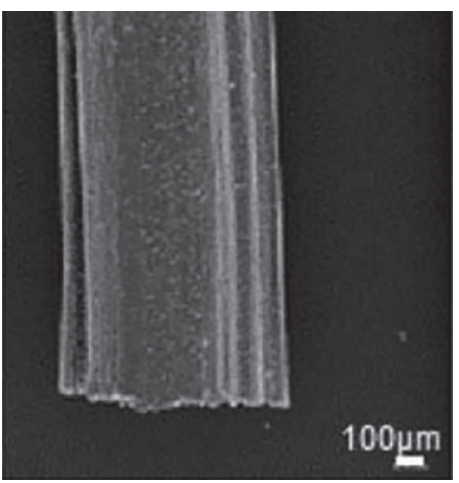

(c)

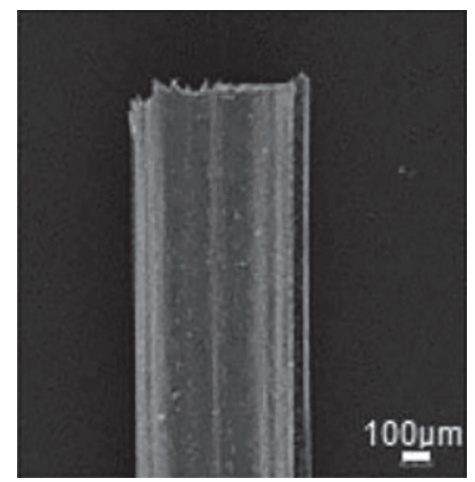

(e)

Figure 1: 5\% NaOH-treated alfa fiber at different time intervals: (a) raw fiber, (b) $2 \mathrm{~h}$, (c) $4 \mathrm{~h}$, (d) $6 \mathrm{~h}$, and (e) 24h [174].
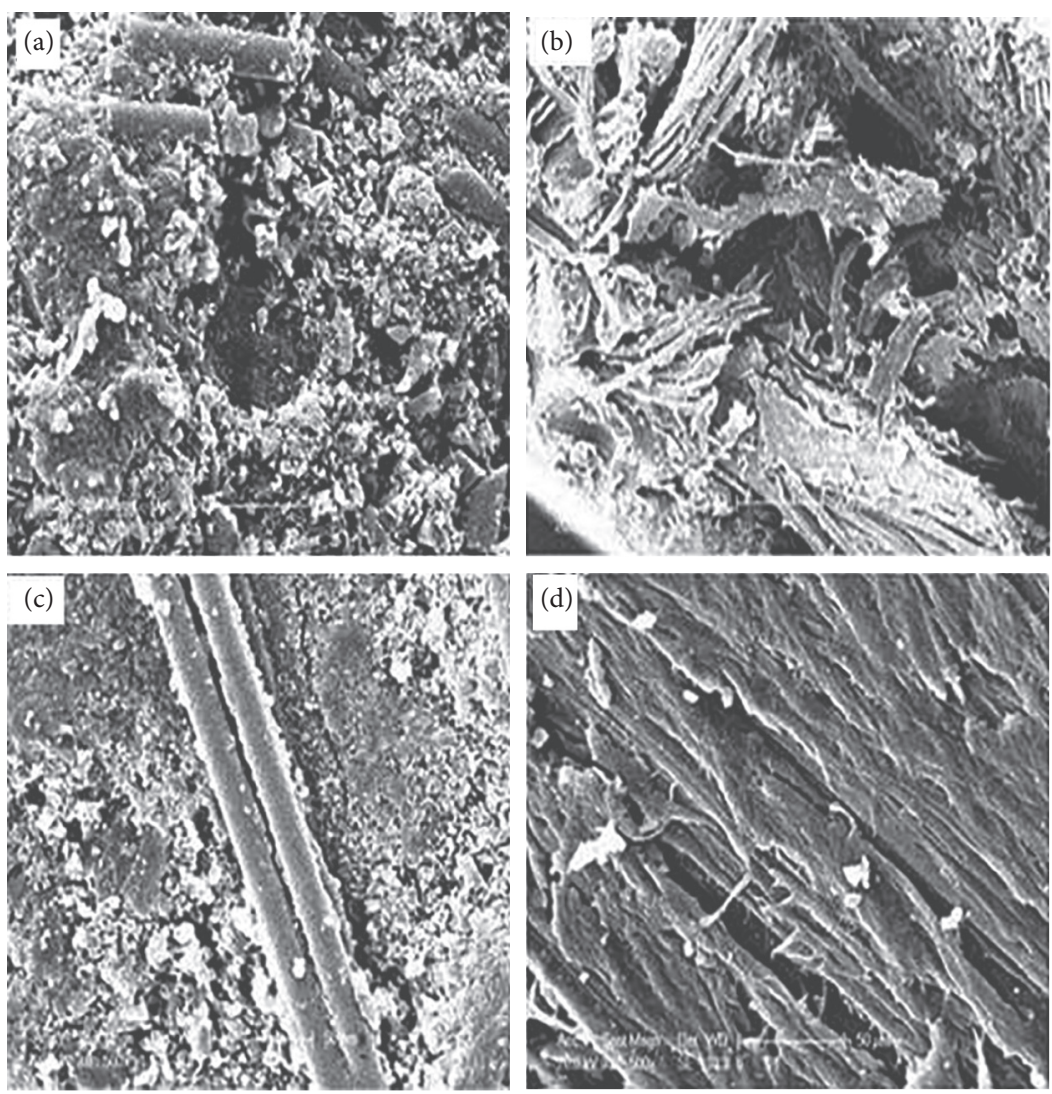

Figure 2: SEM images. (a) Untreated Prosopis juliflora fiber. (b) $15 \% \mathrm{NaOH}$-treated fiber. (c) $10 \% \mathrm{NaOH}$-treated fiber. (d) $5 \% \mathrm{NaOH}$ treated fiber [175]. 


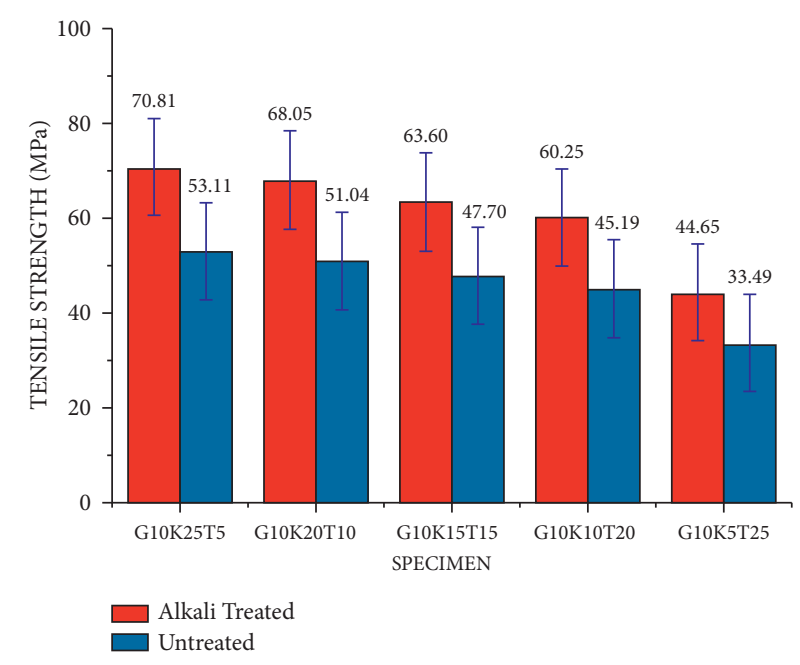

(a)

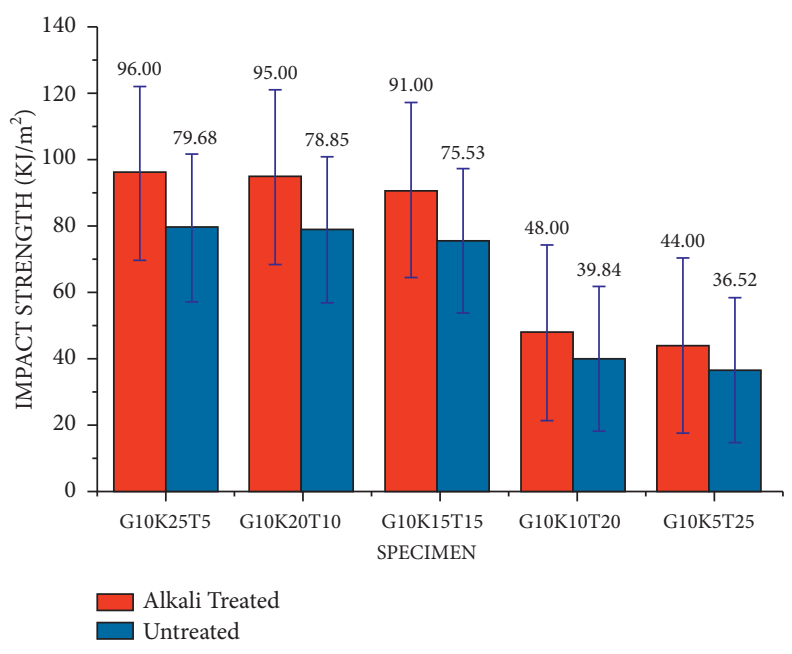

(c)

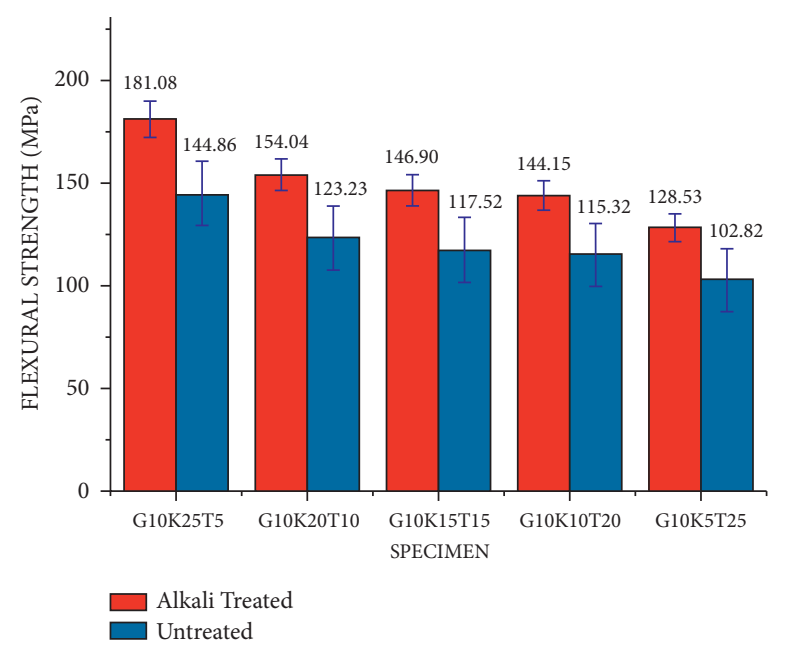

(b)

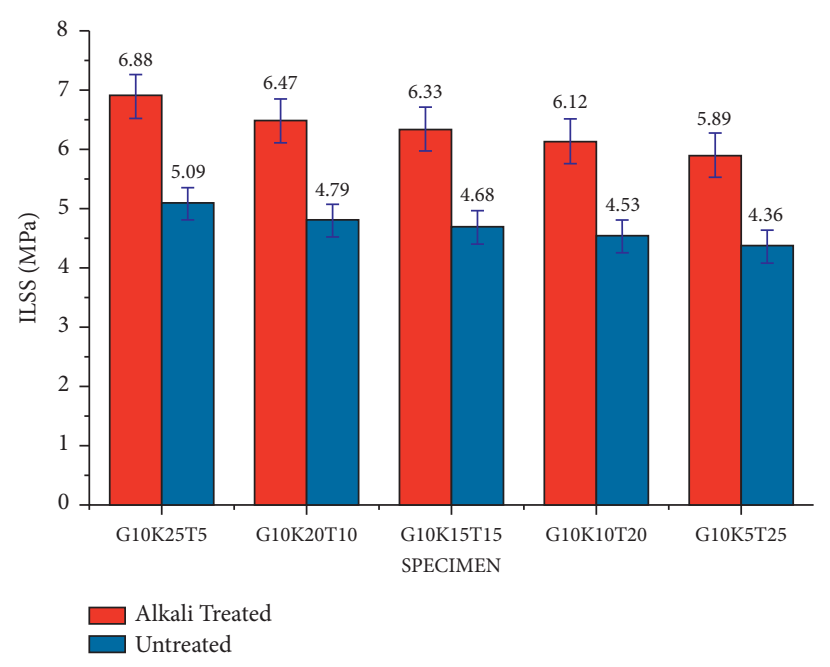

(d)

FIgURe 3: Tensile, flexural, impact, and interlaminar shear strength of glass/kenaf/tea leaf fiber-reinforced hybrid composites: effect of 5\% $\mathrm{NaOH}$ alkaline treatment [12].

surface be rough enough has happened. Overall it was concluded that coconut sheath fiber-reinforced polyester composites could be a vital replacement for glass fiberreinforced polymer composites. Kim et al. [179] studied the influence of bamboo fibers extracted by subjecting the fibers to steam explosion, alkalization, and chemical extraction. The conversion rate from raw source to extracted fiber was found to be significant for alkali extraction method. Then the extracted fibers were subjected to alkali, silane, and combined treatment with different proportion to study the optimal and suitable pretreatment type for bamboo fiber. The tensile strength and modulus of mercerized bamboo fibers were found to be superior when compared to silane and alkali/silane modified bamboo fibers. But the mechanical property of composites was found to be higher for alkali/silane-treated bamboo fiber-reinforced composites. Finally the water intake characteristics of alkali and alkali/ silane-treated bamboo fiber-reinforced vinyl ester composites were better when compared to bamboo fiber- reinforced vinyl ester composites. Liu et al. [177] explored the silane coupling agent's influence on the tribological behaviour of corn stalk fiber-reinforced polymer composites. The silane treatment of fibril resulted in enhanced wear resistance; however, friction performance was not effective. The examination of worn surface morphology revealed the emergence of secondary plateau on the composite surface which enhanced the tribological characteristics of the composites. Lai et al. [180] investigated the possibility of fabricating fiber-reinforced polymer composites using coconut coir fiber as reinforcement material. The coconut coir fibers were exposed to mercerization followed by permanganate and stearic acid modifications to improve the effective adherence between the fiber and matrix. The fibrils were sized to $0.3 \mathrm{~mm}$ and $0.5 \mathrm{~mm}$ during the fabrication of the composites. Tensile and flexural strength results revealed that when the percentage of fiber loading increased, the strength values decreased. This was due to the inability of the fiber to support the stress shifting from the polypropylene 

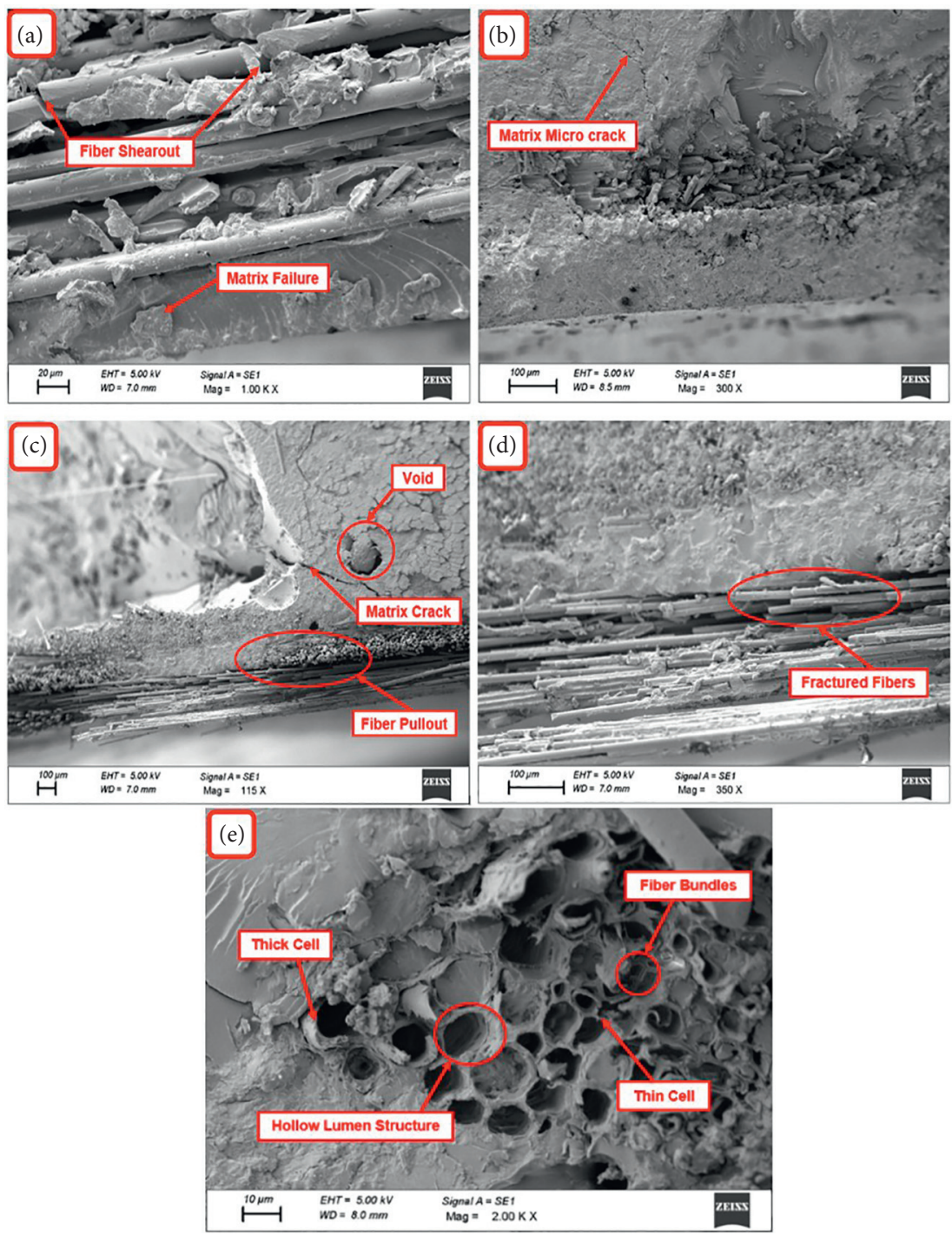

FIGURE 4: SEM micrographs of (a) tensile test of 5\% NaOH-treated composites, (b) matrix microcrack, (c) fiber pull-out and void formation in the impact test specimen, (d) fractured surface of impact test specimen, and (e) hollow structure of natural hybrid fiber composites [12].

matrix and due to poor reinforcement property. Tensile and flexural modulus increased with increase in fiber loading, which was because of the higher fiber size, and this can also be inferred based on the aspect ratio of the fibrils. Zaman and Beg [119] evaluated the mechanical characteristics of banana fiber-strands-reinforced low density polyethylene matrix. The banana fiber strands were pretreated with methylacrylate (MA) solution combined with methanol and benzyl peroxide. The mechanical properties improved as a result of better adherence between the interface of banana fiber strand and polyethylene matrix. The banana fiber strands modified with starch solution showed improvement in composite properties against methylacrylate-treated fiber. Joseph et al. [161] studied the effects of benzoyl chloride treatment on sisal fiber and found maximum thermal stability compared to raw fiber composites. The treatment removes the hemicellulose and fatty substance in fiber surfaces for better mechanical and thermal properties. The sisal/glass/filler/epoxy reinforced composites were used in the frames, toys, and electronic panels. Sampathkumar et al. [181] analysed the influence of surface treatment on water absorption nature of Areca fiber. Due to the presence of hydroxide and other constituents in chemicals, the water absorption nature was higher and this leads to poor wettability. The results of their work concluded that there was a reduction in water absorption during acetylation of Areca fiber and increase in water absorption in treatment with alkali. Alfa fibers were kept under the various fiber surface treatments involving acetylating and it was confirmed that the treatment enhanced the resistance of fiber to moisture $[182,183]$. Bisanda [184] reported that alkali-treated sisal fiber-reinforced polylactic acid composites removed lignin and waxy substances which led to better mechanical interlocking. The tensile, flexural, impact, and interlaminar shear strength (ILSS) of $5 \% \mathrm{NaOH}$-treated kenaf and tea leaf fibers-reinforced composites improved by $33.32 \%$, 25\%, $20.48 \%$, and $35.16 \%$, respectively, when compared with untreated composites due to removal of hemicellulose, 


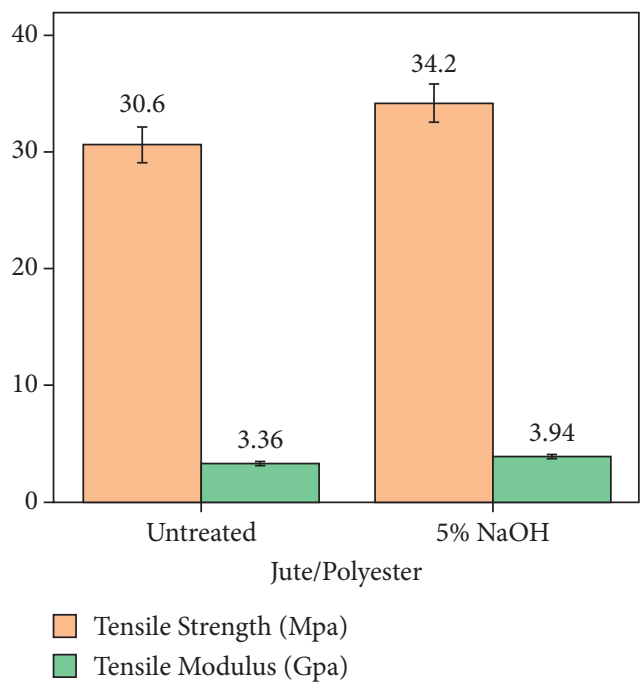

(a)

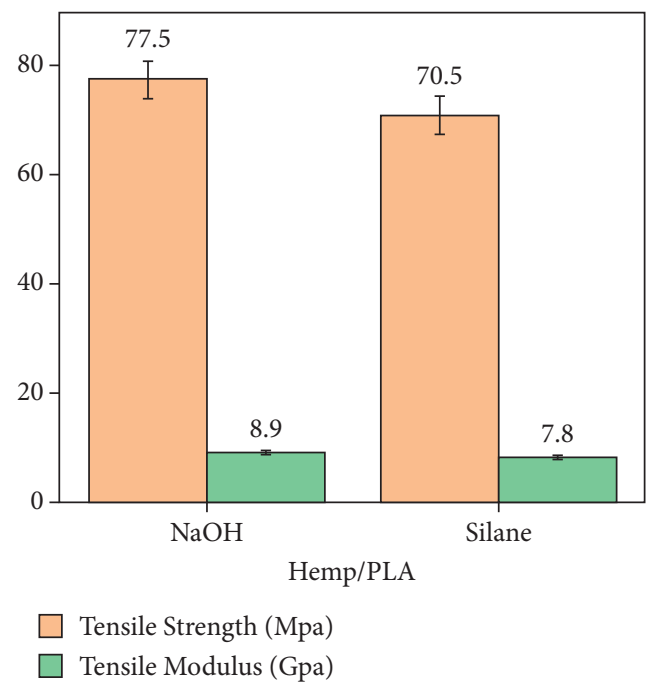

(b)

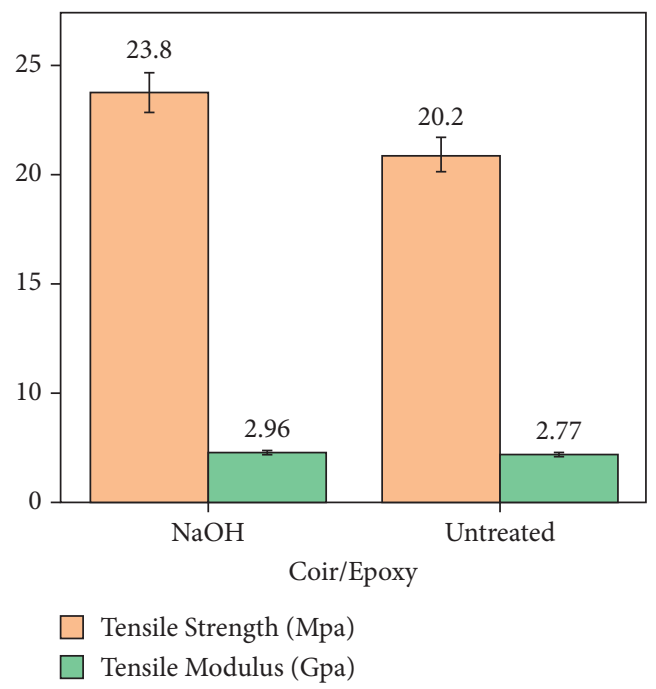

(c)

Figure 5: Tensile properties of 5\% NaOH-treated jute/polyester and hemp/PLA composites [190].

lignin, pectin, and waxy elements which resulted in better interactions between hydrophilic fiber and hydrophobic matrix [12]. Figure 3 presents the mechanical properties of glass/kenaf/tea leaf fiber-reinforced hybrid composites.

The SEM analysis (Figure 4) shows that mechanical properties of untreated fiber composites were decreased by the problems such as fiber breakage, fiber pull-out, formation of micro voids, and nonuniform distribution of fiber and matrix. The 5\% $\mathrm{NaOH}$-treated kenaf and tea leaf fiber improved the adhesion between the fiber and matrix which resulted in better mechanical properties [12].

The biodegradability of chemically modified cellulosic fibers is associated with physical, chemical, mechanical, and thermal properties $[5,185,186]$. The agricultural waste fiberreinforced composites are used in automobile, aerospace, construction materials, packaging applications, and medical applications. Sharma and Kumar [187] studied the tensile properties of sugar palm fiber obtained from different height of the palm plant. The tensile properties enhanced in the bottom part of the tree fiber due to their chemical composition, particularly cellulose, hemicellulose, and lignin [188, 189].

The tensile strength and tensile modulus of $5 \% \mathrm{NaOH}-$ treated jute fiber-reinforced polyester composites improved by $5.2 \%$ and $17.2 \%$, respectively, when compared with untreated composites due to better interaction between fiber and matrix (Figure 5). It was also revealed that $5 \% \mathrm{NaOH}-$ treated hemp fiber-reinforced PLA composites exhibited outstanding results compared to silane-treated hemp fiberreinforced PLA composites [190]. The tensile strength and tensile modulus of $5 \% \mathrm{NaOH}$-treated hemp fiber-reinforced PLA composites improved by $9.9 \%$ and $14.1 \%$, respectively, when compared with silane-treated composites owing to better removal of unwanted substances such as hemicellulose and waxy elements. Likewise, 5\% NaOH-treated coir fiber-reinforced epoxy composites exhibited superior tensile 
properties such as tensile strength (17.8\%) and tensile modulus $(6.8 \%)$ compared to untreated fiber composites. Based on various chemical treatments, alkaline treatment $(5 \% \mathrm{NaOH})$ is the most economical and effective treatment in promoting better communications between fiber and matrix by removal of hemicellulose, lignin, and waxy elements due to disruption of hydrogen bonding in the fiber structure, thus resulting in better mechanical and thermal properties.

\section{Conclusions}

In this detailed review, the effects of various chemical treatments on different biofiber-reinforced composites were summarized. Furthermore, the effect of constitution of biofibers was also reported. The physical, mechanical, and thermal properties of various biofibers-reinforced composites were improved up on modification of fiber surfaces, while fiber swelling effect and water absorption rate were decreased by various chemical treatments like alkaline, silane, acetylation, permanganate, peroxide, benzoylation, acrylonitrile grafting, maleic anhydride grafted, acrylation, and isocyanate. Based on various chemical treatments, alkaline treatment $(5 \% \mathrm{NaOH})$ is the most economical and effective treatment in promoting better communications between fiber and matrix by removal of hemicellulose, lignin, and waxy elements due to disruption of hydrogen bonding in the fiber structure, thus resulting in better mechanical and thermal properties. It was concluded that alkaline treatment of fibers with $5 \mathrm{wt} \% \mathrm{NaOH}$ made the fibers more resistant to deformation and heat. The alkaline treatment has been one of the successful methods used to treat the natural fibers in order to achieve better results.

\section{Data Availability}

The data used to support the findings of this study are included within the article.

\section{Conflicts of Interest}

The authors declare that there are no conflicts of interest regarding the publication of this article.

\section{Acknowledgments}

Alagar Karthick gratefully acknowledges group FQM-383 from Universidad de Cordoba, Spain, for the provision of an honorary visiting research position in the group. This project was funded by a Researchers Supporting Project (no. RSP2021/405), King Saud University, Riyadh, Saudi Arabia.

\section{References}

[1] M. Ramesh, L. RajeshKumar, and V. Bhuvaneshwari, "Bamboo fiber reinforced composites," in Bamboo Fiber Composites. Composites Science and Technology, M. Jawaid, S. MavinkereRangappa, and S. Siengchin, Eds., Springer, Singapore, pp. 1-13, 2021.
[2] S. Sathish, L. Prabhu, S. Gokulkumar, N. Karthi, D. Balaji, and N. Vigneshkumar, "Extraction, treatment and applications of natural fibers for bio-composites-a critical review," International Polymer Processing, vol. 36, no. 2, pp. 114-130, 2021.

[3] M. Ramesh, C. Deepa, L. R. Kumar, M. Sanjay, and S. Siengchin, "Life-cycle and environmental impact assessments on processing of plant fibres and its bio-composites: a critical review," Journal of Industrial Textiles, Article ID 152808372092473, 2020.

[4] L. Prabhu, V. Krishnaraj, S. Sathish et al., "A review on natural fiber reinforced hybrid composites: chemical treatments, manufacturing methods and potential applications," Materials Today Proceedings, vol. 45, pp. 8080-8085, 2021.

[5] J. Holbery and D. Houston, "Natural-fiber-reinforced polymer composites in automotive applications," Journal of Occupational Medicine, vol. 58, no. 11, pp. 80-86, 2006.

[6] M. Ramesh, J. Maniraj, and L. Rajesh Kumar, "Biocomposites for energy storage," in Biobased Composites: Processing, Characterization, Properties, and Applications, A. Khan, M. Sanjay, Rangappa, and A. M. A. SuchartSiengchin, Eds., Wiley Online Library, Hoboken, NJ, USA, pp. 123-142, 2021.

[7] L. Prabhu, V. Krishnaraj, S. Sathish, S. Gokulkumar, M. R. Sanjay, and S. Siengchin, "Mechanical and acoustic properties of alkali-treated sansevieria ehrenbergii/camellia sinensis fiber-reinforced hybrid epoxy composites: incorporation of glass fiber hybridization," Applied Composite Materials, vol. 27, no. 6, pp. 915-933, 2020.

[8] M. Jawaid and H. P. S. Abdul Khalil, "Cellulosic/synthetic fibre reinforced polymer hybrid composites: a review," Carbohydrate Polymers, vol. 86, no. 1, pp. 1-18, 2011.

[9] M. Ramesh, L. Rajeshkumar, D. Balaji, and V. Bhuvaneswari, "Green composite using agricultural waste reinforcement," in Green Composites. Materials Horizons: From Nature to Nanomaterials, S. Thomas and P. Balakrishnan, Eds., Springer, Singapore, pp. 21-34, 2021.

[10] O. Faruk, A. K. Bledzki, H.-P. Fink, and M. Sain, "Biocomposites reinforced with natural fibers: 2000-2010," Progress in Polymer Science, vol. 37, no. 11, pp. 1552-1596, 2012.

[11] N. Karthi, K. Kumaresan, S. Sathish, S. Gokulkumar, L. Prabhu, and N. Vigneshkumar, "An overview: natural fiber reinforced hybrid composites, chemical treatments and application areas," Materials Today Proceedings, vol. 27, no. 3, pp. 2828-2834, 2020.

[12] L. Prabhu, V. Krishnaraj, S. GokulKumar, S. Sathish, M. Sanjay, and S. Siengchin, "Mechanical, chemical and sound absorption properties of glass/kenaf/waste tea leaf fiber-reinforced hybrid epoxy composites," Journal of Industrial Textiles, Article ID 152808372095739, 2020.

[13] M. Ramesh, L. Rajeshkumar, C. Deepa, M. Tamil Selvan, V. Kushvaha, and M. Asrofi, "Impact of silane treatment on characterization of ipomoea staphylina plant fiber reinforced epoxy composites," Journal of Natural Fibers, vol. 2021, Article ID 1902896, 12 pages, 2021.

[14] L. Prabhu, V. Krishnaraj, S. Sathish, S. GokulKumar, and N. Karthi, "Study of mechanical and morphological properties of jute-tea leaf fiber reinforced hybrid composites: effect of glass fiber hybridization," Materials Today Proceedings, vol. 27, pp. 2372-2375, 2020.

[15] T. Gurunathan, S. Mohanty, and S. K. Nayak, "A review of the recent developments in biocomposites based on natural 
fibres and their application perspectives," Composites Part A: Applied Science and Manufacturing, vol. 77, pp. 1-25, 2015.

[16] D. Mohankumar, V. Amarnath, V. Bhuvaneswari et al., "Extraction of plant based natural fibers-a mini review," IOP Conference Series: Materials Science and Engineering, vol. 1145, no. 1, Article ID 012023, 2021.

[17] D. N. Saheb and J. P. Jog, "Natural fiber polymer composites: a review," Advances in Polymer Technology, vol. 18, no. 4, pp. 351-363, 1999.

[18] L. Mohammed, M. N. M. Ansari, and G. Pua, M. Jawaid and M. S. Islam, A review on natural fiber reinforced polymer composite and its applications," International Journal of Polymer Science, vol. 2015, Article ID 243947, 15 pages, 2015.

[19] P. Balakrishnan, M. J. John, L. Pothen, M. S. Sreekala, and S. Thomas, Advanced Composite Materials for Aerospace Engineering, Wood Head Publishing, Elsevier, Cambridge, UK, 2016.

[20] W. Wang, M. Sain, and P. A. Cooper, "Study of moisture absorption in natural fiber plastic composites," Composites Science and Technology, vol. 66, no. 3, pp. 379-386, 2006.

[21] S. Sathish, N. Karthi, L. Prabhu et al., "A review of natural fiber composites: extraction methods, chemical treatments and applications," Materials Today Proceedings, vol. 45, pp. 8017-8023, 2021.

[22] N. Karthi, K. Kumaresan, G. Rajeshkumar, S. Gokulkumar, and S. Sathish, "Tribological and thermo-mechanical performance of chemically modified musa acuminata/corchorus capsularis reinforced hybrid composites," Journal of Natural Fibers, vol. 2021, Article ID 1870614, 14 pages, 2021.

[23] M. Ramesh, L. Rajeshkumar, and D. Balaji, "Mechanical and dynamic properties of ramie fiber-reinforced composites," in Mechanical and Dynamic Properties of Biocomposites, R. Nagarajan, S. Muthu, K. Thiagamani, S. Krishnasamy, and S. Siengchin, Eds., Wiley, Weinheim, Germany, pp. 275-291, 2021.

[24] C. Udaya Kiran, G. Ramachandra Reddy, B. M. Dabade, and S. Rajesham, "Tensile properties of sun hemp, banana and sisal fiber reinforced polyester composites," Journal of Reinforced Plastics and Composites, vol. 26, no. 10, pp. 1043-1050, 2007.

[25] K. Ramanaiah, A. V. Ratna Prasad, K. H. Chandra Reddy, and K. Hema Chandra Reddy, "Mechanical properties and thermal conductivity of typha angustifolia natural fiberreinforced polyester composites," International Journal of Polymer Analysis and Characterization, vol. 16, no. 7, pp. 496-503, 2011.

[26] R. A. V. Prasad and M. K. Rao, “_Mechanical properties of natural fibre reinforced polyester composites," Jowar, sisal and bamboo; Materials and Design, vol. 32, no. 8, pp. 4658-4663, 2011.

[27] A. Shalwan and B. F. Yousif, "In state of art: mechanical and tribological behaviour of polymeric composites based on natural fibres," Materials \& Design, vol. 48, pp. 14-24, 2013.

[28] V. Mishra and S. Biswas, "Physical and mechanical properties of bi-directional jute fiber epoxy composites," Procedia Engineering, vol. 51, pp. 561-566, 2013.

[29] D. B. Dittenber and H. V. S. GangaRao, "Critical review of recent publications on use of natural composites in infrastructure," Composites Part A: Applied Science and Manufacturing, vol. 43, no. 8, pp. 1419-1429, 2012.

[30] M. R. Ishak, S. M. Sapuan, Z. Leman, M. Z. A. Rahman, and U. M. K. Anwar, "Characterization of sugar palm (Arenga pinnata) fibres," Journal of Thermal Analysis and Calorimetry, vol. 109, no. 2, pp. 981-989, 2011.
[31] J. George, J. Ivens, and I. Verpoest, "Surface modification to improve the impact performance of natural fibre composites," in Proceedings of the 12th International Conference on Composite Materials, ICCM-12, pp. 7-9, Paris, France, July 1999.

[32] S. Sathish, T. Ganapathy, and T. Bhoopathy, "Experimental testing on hybrid composite materials," Applied Mechanics and Materials, vol. 592-594, pp. 339-343, 2014.

[33] M. Kumaresan, S. Sathish, and N. Karthi, "Effect of fiber orientation on mechanical properties of sisal fiber reinforced epoxy composites," Journal of Applied Science and Engineering, vol. 18, pp. 289-294, 2015.

[34] M. Ramesh, C. Deepa, K. Niranjana, L. Rajeshkumar, R. Bhoopathi, and D. Balaji, "Influence of Haritaki (Terminalia chebula) nano-powder on thermo-mechanical, water absorption and morphological properties of Tindora (Coccinia grandis) tendrils fiber reinforced epoxy composites," Journal of Natural Fibers, vol. 2021, Article ID 1921660, 17 pages, 2021.

[35] M. Ramesh, C. Deepa, L. Rajeshkumar, M. Tamil Selvan, and D. Balaji, "Influence of fiber surface treatment on the tribological properties of Calotropis gigantea plant fiber reinforced polymer composites," Polymer Composites, vol. 42, no. 9, pp. 4308-4317, 2021.

[36] L. Prabhu, V. Krishnaraj, S. Gokulkumar, S. Sathish, and M. Ramesh, "Mechanical, chemical and acoustical behavior of sisal - tea waste - glass fiber reinforced epoxy based hybrid polymer composites," Materials Today Proceedings, vol. 16, pp. 653-660, 2019.

[37] S. Sathish, K. Kumaresan, L. Prabhu, and N. Vigneshkumar, "Experimental investigation on volume fraction of mechanical and physical properties of flax and bamboo fibers reinforced hybrid epoxy composites," Polymers and Polymer Composites, vol. 25, no. 3, pp. 229-236, 2017.

[38] S. Sathish, K. Kumaresan, L. Prabhu, and S. Gokulkumar, "Experimental investigation on mechanical and FTIR analysis of flax fiber/epoxy composites incorporating $\mathrm{SiC}$, $\mathrm{Al}_{2} \mathrm{O}_{3}$ and graphite," Romanian Journal of Materials, vol. 48, pp. 476-482, 2018.

[39] N. Karthi, K. Kumaresan, S. Sathish et al., "Effect of weight fraction on the mechanical properties of flax and jute fibers reinforced epoxy hybrid composites," Materials Today Proceedings, vol. 45, pp. 8006-8010, 2021.

[40] A. George, M. R. Sanjay, R. Srisuk, J. Parameswaranpillai, and S. Siengchin, "A comprehensive review on chemical properties and applications of biopolymers and their composites," International Journal of Biological Macromolecules, vol. 154, pp. 329-338, 2020.

[41] S. Kobayashi, K. Takada, and R. Nakamura, "Processing and characterization of hemp fiber textile composites with microbraiding technique," Composites Part A: Applied Science and Manufacturing, vol. 59, pp. 1-8, 2014.

[42] M. A. Alam, K. Alriyami, M. Z. Jumaat, and Z. C. Muda, "Development of high strength natural fibre based composite plates for potential application in retrofitting of RC structure," Indian Journal of Science and Technology, vol. 8, p. 15, 2015.

[43] M. Z. Rong, M. Q. Zhang, Y. Liu, G. C. Yang, and H. M. Zeng, "The effect of fiber treatment on the mechanical properties of unidirectional sisal-reinforced epoxy composites," Composites Science and Technology, vol. 61, no. 10, pp. 1437-1447, 2001.

[44] Z. Wang, L. Dadi Bekele, Y. Qiu et al., "Preparation and characterization of coffee hull fiber for reinforcing 
application in thermoplastic composites," Bioengineered, vol. 10, no. 1, pp. 397-408, 2019.

[45] A. K. Rout, J. Kar, D. K. Jesti, and A. K. Sutar, "Effect of surface treatment on the physical, chemical', and mechanical properties of palm tree leaf stalk fibers," Bioresources, vol. 11, pp. 4432-4445, 2016.

[46] S. S. Tripathy, S. Jena, S. B. Misra, N. P. Padhi, and B. C. Singh, "A study on graft copolymerization of methyl methacrylate onto jute fiber," Journal of Applied Polymer Science, vol. 30, no. 4, pp. 1399-1406, 1985.

[47] N. A. Nor Azowa Ibrahim, K. A. Kamarul Arifin Hadithon, and K. Abdan, "Effect of fiber treatment on mechanical properties of kenaf fiber-ecoflex composites," Journal of Reinforced Plastics and Composites, vol. 29, no. 14, pp. 2192-2198, 2010.

[48] M. John and S. Thomas, "Biofibres and biocomposites," Carbohydrate Polymers, vol. 71, no. 3, pp. 343-364, 2008.

[49] A. M. M. Edeerozey, H. M. Akil, A. B. Azhar, and M. I. Z. Ariffin, "Chemical modification of kenaf fibers," Materials Letters, vol. 61, no. 10, pp. 2023-2025, 2007.

[50] A. Valadez-Gonzalez, J. M. Cervantes-Uc, R. Olayo, and P. J. Herrera-Franco, "Effect of fiber surface treatment on the fiber-matrix bond strength of natural fiber reinforced composites," Composites Part B: Engineering, vol. 30, no. 3, pp. 309-320, 1999.

[51] N. S. Venkatesha Gupta, K. V. Akash, K. V. Sreenivasa Rao, and D. S. Arun kumar, "Fabrication and evaluation of mechanical properties of alkaline treated sisal/hemp fiber reinforced hybrid composite," IOP Conference Series: Materials Science and Engineering, vol. 149, Article ID 012093, 2016.

[52] K. Athipathi and V. Hegde Sowmitha Vijay, "Evaluation of mechanical behavior of natural fiber hybrid composite material," International Journal of Advanced Research in Science, Engineering and Technology, vol. 3, no. 5, pp. 2041-2049, 2016.

[53] S. Sathish, K. Kumaresan, L. Prabhu, S. Gokulkumar, N. Karthi, and N. Vigneshkumar, "Experimental investigation of mechanical and morphological properties of flax fiber reinforced epoxy composites incorporating $\mathrm{SiC}$ and $\mathrm{Al}_{2} \mathrm{O}_{3}$," Materials Today Proceedings, vol. 27, pp. 2249-2253, 2020.

[54] S. Gokulkumar, P. R. Thyla, L. Prabhu, S. Sathish, and N. Karthi, "A comparative study on epoxy based composites filled with pineapple/areca/ramie hybridized with industrial tea leaf wastes/GFRP," Materials Today Proceedings, vol. 27, pp. 2474-2476, 2020.

[55] A. Oushabi, S. Sair, F. Oudrhiri Hassani, Y. Abboud, O. Tanane, and A. El Bouari, "The effect of alkali treatment on mechanical, morphological and thermal properties of date palm fibers (DPFs): study of the interface of DPFPolyurethane composite," South African Journal of Chemical Engineering, vol. 23, pp. 116-123, 2017.

[56] M. H. Hamidon, M. T. H. Sultan, A. H. Ariffin, and A. U. M. Shah, "Effects of fibre treatment on mechanical properties of kenaf fibre reinforced composites: a review," Journal of Materials Research and Technology, vol. 8, no. 3, pp. 3327-3337, 2019.

[57] M. Cai, H. Takagi, A. N. Nakagaito, Y. Li, and G. I. N. Waterhouse, "Effect of alkali treatment on interfacial bonding in abaca fiber-reinforced composites," Composites Part A: Applied Science and Manufacturing, vol. 90, pp. 589-597, 2016.

[58] H. Chen, W. Zhang, X. Wang et al., "Effect of alkali treatment on wettability and thermal stability of individual bamboo fibers," Journal of Wood Science, vol. 64, no. 4, pp. 398-405, 2018.

[59] K. O. Reddy, M. Shukla, C. U. Maheswari, and A. V. Rajulu, "Evaluation of mechanical behavior of chemically modified Borassus fruit short fiber/unsaturated polyester composites," Journal of Composite Materials, vol. 46, no. 23, pp. 29872998, 2012.

[60] A. Balaji and K. Nagarajan, "Characterization of alkali treated and untreated new cellulosic fiber from Saharan aloe vera cactus leaves," Carbohydrate Polymers, vol. 174, pp. 200-208, 2017.

[61] J. B. Dawit, Y. Regassa, and H. G. Lemu, "Property characterization of acacia tortilis for natural fiber reinforced polymer composite," Results in Materials, vol. 5, Article ID 100054, 2020.

[62] P. Narayanasamy, P. Balasundar, S. Senthil et al., "Characterization of a novel natural cellulosic fiber from Calotropis gigantea fruit bunch for ecofriendly polymer composites," International Journal of Biological Macromolecules, vol. 150, pp. 793-801, 2020.

[63] T. A. Negawo, Y. Polat, F. N. Buyuknalcaci, A. Kilic, N. Saba, and M. Jawaid, "Mechanical, morphological, structural and dynamic mechanical properties of alkali treated Ensete stem fibers reinforced unsaturated polyester composites," Composite Structures, vol. 207, pp. 589-597, 2019.

[64] K. H. Reddy, R. M. Reddy, M. Ramesh, D. MohanaKrishnudu, B. M. Reddy, and H. R. Rao, "Impact of alkali treatment on characterization of Tapsi (SterculiaUrens) natural bark fiber reinforced polymer composites," Journal of Natural Fibers, vol. 2019, Article ID 1623747, 12 pages, 2019.

[65] K. Senthilkumar, N. Saba, N. Rajini et al., "Mechanical properties evaluation of sisal fibre reinforced polymer composites: a review," Construction and Building Materials, vol. 174, pp. 713-729, 2018.

[66] A. Balaji, B. Karthikeyan, J. Swaminathan, and C. S. Raj, "Effect of filler content of chemically treated short bagasse fiber-reinforced cardanol polymer composites," Journal of Natural Fibers, vol. 16, pp. 1-15, 2018.

[67] U. K. Komal, V. Verma, T. Ashwani, N. Verma, and I. Singh, "Effect of chemical treatment on thermal, mechanical and degradation behavior of banana fiber reinforced polymer composites," Journal of Natural Fibers, vol. 17, no. 7, pp. 1026-1038, 2018.

[68] M. H. Ameer, K. Shaker, M. Ashraf et al., "Interdependence of moisture, mechanical properties, and hydrophobic treatment of jute fibre-reinforced composite materials," Journal of the Textile Institute, vol. 108, no. 10, pp. 1768-1776, 2017.

[69] S. C. Chin, K. F. Tee, F. S. Tong, H. R. Ong, and J. Gimbun, "Thermal and mechanical properties of bamboo fiber reinforced composites," Materials Today Communications, vol. 23, Article ID 100876, 2020.

[70] P. Senthamaraikannan, S. S. Saravanakumar, M. R. Sanjay, M. Jawaid, and S. Siengchin, "Physico-chemical and thermal properties of untreated and treated Acacia planifrons bark fibers for composite reinforcement," Materials Letters, vol. 240, pp. 221-224, 2019.

[71] M. Asim, M. Jawaid, K. Abdan, and M. R. Ishak, "Effect of alkali and silane treatments on mechanical and fibre-matrix bond strength of kenaf and pineapple leaf fibres," Journal of Bionics Engineering, vol. 13, no. 3, pp. 426-435, 2016.

[72] A. Rachini, M. Le Troedec, C. Peyratout, and A. Smith, "Chemical modification of hemp fibers by silane coupling 
agents," Journal of Applied Polymer Science, vol. 123, no. 1, pp. 601-610, 2012.

[73] S. Radoor, J. Karayil, S. M. Rangappa, S. Siengchin, and J. Parameswaranpillai, "A review on the extraction of pineapple, sisal and abaca fibers and their use as reinforcement in polymer matrix," Express Polymer Letters, vol. 14, no. 4, pp. 309-335, 2020.

[74] M. S. Huda, L. T. Drzal, D. Ray, A. K. Mohanty, and M. Mishra, "Natural-fiber composites in the automotive sector," Properties and Performance of Natural-Fibre Composites, Woodhead Publishing, Sawston, UK, pp. 221-268, 2008.

[75] J. Naveen, M. Jawaid, P. Amuthakkannan, and M. Chandrasekar, "Mechanical and physical properties of sisal and hybrid sisal fiber-reinforced polymer composites," in Mechanical and Physical Testing of Biocomposites, FibreReinforced Composites and Hybrid Composites, pp. 427-440, Woodhead Publishing, Sawston, UK, 2019.

[76] M. Hashim, M. Roslan, A. Amin, A. Zaidi, and S. Ariffin, "Mercerization treatment parameter effect on natural fiber reinforced polymer matrix composite: a brief review," International Journal of Materials and Metallurgical Engineering, vol. 6, no. 8, pp. 784-790, 2012.

[77] V. K. Balla, K. H. Kate, J. Satyavolu, P. Singh, and J. G. D. Tadimeti, "Additive manufacturing of natural fiber reinforced polymer composites: processing and prospects," Composites Part B: Engineering, vol. 174, Article ID 106956, 2019.

[78] M. Sakthivel, S. Vijayakumar, and S. Ramesh, "Production and characterization of luffa/coir reinforced polypropylene composite," Procedia Materials Science, vol. 5, pp. 739-745, 2014.

[79] R. Panneerdhass, A. Gnanavelbabu, and K. Rajkumar, "Mechanical properties of luffa fiber and ground nut reinforced epoxy polymer hybrid composites," Procedia Engineering, vol. 97, pp. 2042-2051, 2014.

[80] R. Punyamurthy, D. Sampathkumar, C. V. Srinivasa, and B. Bennehalli, "Effect of alkali treatment on water absorption of single cellulosic abaca fiber," Bioresources, vol. 7, pp. 3515-3524, 2012.

[81] K. Kaewtatip and J. Thongmee, "Studies on the structure and properties of thermoplastic starch/luffa fiber composites," Materials \& Design, vol. 40, pp. 314-318, 2012.

[82] M. Ashok Kumar, G. Ramachandra Reddy, H. Raghavendra Rao, K. Hemachandra Reddy, and B. H. Nanjunda Reddy, "Assessment of glass/drumstick fruit fiber (moringa oleifera) reinforced epoxy hybrid composites," International Journal of Polymeric Materials, vol. 61, no. 10, pp. 759-767, 2012.

[83] S. I. Hossain, M. Hasan, M. N. Hasan, and A. Hassan, "Effect of chemical treatment on physical, mechanical and thermal properties of ladies finger natural fiber," Advances in $M a$ terials Science and Engineering, vol. 2013, Article ID 824274, 6 pages, 2013.

[84] G. Ramachandra Reddy, M. Ashok Kumar, N. Karthikeyan, and S. Mahaboob Basha, "Tamarind fruit fiber and glass fiber reinforced polyester composites," Mechanics of Advanced Materials and Structures, vol. 22, no. 9, pp. 770-775, 2014.

[85] R. Vinayagamoorthy and N. Rajeswari, "Mechanical performance studies on Vetiveria zizanioides/jute/glass fiberreinforced hybrid polymeric composites," Journal of Reinforced Plastics and Composites, vol. 33, no. 1, pp. 81-92, 2013.

[86] L. Boopathi, P. S. Sampath, and K. Mylsamy, "Investigation of physical, chemical and mechanical properties of raw and alkali treated Borassus fruit fiber," Composites Part B: Engineering, vol. 43, no. 8, pp. 3044-3052, 2012.

[87] A. Tlijani, R. Gouadria, J. F. Ben YounÃs, A. Durastanti, and M. Mazioud, "Study and optimization of palm wood mechanical properties by alkalization of the natural fiber," Global Journal of Science Frontier Research, vol. 11, no. 1, 2014.

[88] D. Shanmugam and M. Thiruchitrambalam, "Static and dynamic mechanical properties of alkali treated unidirectional continuous Palmyra palm leaf stalk fiber/jute fiber reinforced hybrid polyester composites," Materials \& Design, vol. 50, pp. 533-542, 2013.

[89] A. Lavoratti, D. Romanzini, S. C. Amico, and A. J. Zattera, "Influence of fibre treatment on the characteristics of buriti and ramie polyester composites," Polymers and Polymer Composites, vol. 25, no. 4, pp. 247-256, 2017.

[90] N. Johar, I. Ahmad, and A. Dufresne, "Extraction, preparation and characterization of cellulose fibres and nanocrystals from rice husk," Industrial Crops and Products, vol. 37, no. 1, pp. 93-99, 2012.

[91] D. Ray, B. K. Sarkar, A. K. Rana, and N. R. Bose, "Effect of alkali treated jute fibres on composite properties," Bulletin of Materials Science, vol. 24, no. 2, pp. 129-135, 2001.

[92] S. V. Prasad, C. Pavithran, and P. K. Rohatgi, "Alkali treatment of coir fibres for coir-polyester composites," Journal of Materials Science, vol. 18, no. 5, pp. 1443-1454, 1983.

[93] D. Ray, B. K. Sarkar, A. K. Rana, and N. R. Bose, "The mechanical properties of vinylester resin matrix composites reinforced with alkali-treated jute fibres," Composites Part A: Applied Science and Manufacturing, vol. 32, no. 1, pp. 119$127,2001$.

[94] N. Venkateshwaran, A. Elaya Perumal, and D. Arunsundaranayagam, "Fiber surface treatment and its effect on mechanical and visco-elastic behaviour of banana/ epoxy composite," Materials \& Design, vol. 47, pp. 151-159, 2013.

[95] C. Qin, N. Soykeabkaew, N. Xiuyuan, and T. Peijs, “The effect of fibre volume fraction and mercerization on the properties of all-cellulose composites," Carbohydrate Polymers, vol. 71, no. 3, pp. 458-467, 2008.

[96] B. Vinod and M. Anandajothi, "Mechanical and tribological properties of abaca-roselle/cardanol formaldehyde hybrid composites," Materials Research Express, vol. 6, no. 12, Article ID 125363, 2020.

[97] A. Lakshmanan, R. K. Ghosh, S. Dasgupta, S. Chakraborty, and P. K. Ganguly, "Optimization of alkali treatment condition on jute fabric for the development of rigid biocomposite," Journal of Industrial Textiles, vol. 47, no. 5, pp. 640-655, 2018.

[98] H. Abdellaoui, H. Bensalah, M. Raji, D. Rodrigue, R. Bouhfid, and A. Qaiss, "Laminated epoxy biocomposites based on clay and jute fibers," Journal of Bionics Engineering, vol. 14, no. 2, pp. 379-389, 2017.

[99] Q. Xie, F. Li, J. Li et al., "A new biodegradable sisal fiberstarch packing composite with nest structure," Carbohydrate Polymers, vol. 189, pp. 56-64, 2018.

[100] M. S. Sreekala, M. G. Kumaran, J. Seena, J. Maya, and T. Sabu, "Oil palm fibre reinforced phenol formaldehyde composites: influence of fibre surface modifications on the mechanical performance," Applied Composite Materials, vol. 7, no. 5-6, pp. 295-329, 2000. 
[101] R. Gunti and V. R. P. Atluri, "Tensile properties of successive alkali treated short jute fiber reinforced PLA composites," Procedia Materials Science, vol. 5, pp. 2188-2196, 2014.

[102] R. P. G. Leela Siva, M. V. H. Satish Kumar, and R. Gunti, "Effect of fibre loading and successive alkali treatments on tensile properties of short jute fibre reinforced polypropylene composites," International Journal of Engineering Science Invention, vol. 3, no. 3, pp. 30-34, 2014.

[103] M. J. M. Ridzuan, M. S. A. Majid, M. Afendi, K. Azduwin, S. N. A. Kanafiah, and Y. Dan-mallam, "The effects of the alkaline treatment's soaking exposure on the tensile strength of napier fibre," Procedia Manufacturing, vol. 2, pp. 353-358, 2015.

[104] N. Mokaloba and R. Batane, "The effects of mercerization and acetylation treatments on the properties of sisal fiber and its interfacial adhesion characteristics on polypropylene," International Journal of Engineering, Science and Technology, vol. 6, no. 4, pp. 83-97, 2014.

[105] P. Augustine, J. Kuruvilla, and T. Sabu, "Effect of surface treatments on the electrical properties of low-density polyethylene composites reinforced with short sisal fibers," Composites Science and Technology, vol. 51, no. 1, pp. 67-79, 1997.

[106] S. M. Mohd, F. O. Muhamad, H. Hazran, F. R. Muhammad, and M. S. Mohd Syahar, "Improving tensile properties of kenaf fibers treated with sodium hydroxide," Procedia Engineering, vol. 41, pp. 1587-1592, 2012.

[107] P. J. Jandas, S. Mohanty, and S. K. Nayak, "Surface treated banana fiber reinforced poly (lactic acid) nanocomposites for disposable applications," Journal of Cleaner Production, vol. 52, pp. 392-401, 2013.

[108] A. P. Sherely, B. Abderrahim, I. Laurent, and C. Yves, "Effect of fiber loading and chemical treatments on thermophysical properties of banana fiber/polypropylene commingled composite materials," Composer Part A, vol. 39, no. 9, pp. 1582-1588, 2008.

[109] J. Seena, P. Koshy, and T. Sabu, "The role of interfacial interactions on the mechanical properties of banana fibre reinforced phenol formaldehyde composites," Composite Interfaces, vol. 12, no. 6, pp. 581-600, 2005.

[110] H. Anshida, B. Panampilly, A. Indose, and T. Sabu, "Studies on tensile and flexural properties of short banana/glass hybrid fiber reinforced polystyrene composites," Journal of Composite Materials, vol. 42, no. 15, pp. 1471-1489, 2008.

[111] J. C. Mejia Osorio, R. Rodriguez-Baracaldo, and J. J. OlayaFlorez, "The influence of alkali treatment on banana fibre's mechanical properties," Ingeniería $e$ Investigación, vol. 32, no. 1, pp. 83-87, 2012.

[112] J. Jain, S. Sinha, and S. Jain, "Compendious characterization of chemically treated natural fiber from pineapple leaves for reinforcement in polymer composites," Journal of Natural Fibers, vol. 2019, Article ID 1658256, 12 pages, 2019.

[113] S. H. Masud, T. D. Lawerence, and K. M. Amar, "Effect of chemical modifications of the pineapple leaf fiber surfaces on the interfacial and mechanical properties of laminated biocomposites," Composite Interfaces, vol. 15, no. 2-3, pp. 169-191, 2008.

[114] P. Threepopnatkul, N. Kaerkitcha, and N. Athipongarporn, "Effect of surface treatment on performance of pineapple leaf fiber-polycarbonate composites," Composites Part B: Engineering, vol. 40, no. 7, pp. 628-632, 2009.

[115] M. Varun and S. Shishir, "Effect of alkali treatment on the thermal properties of wheat straw fiber reinforced epoxy composites," Journal of Composite Materials, vol. 51, no. 3, pp. 323-331, 2016.

[116] K. L. Pickering, M. A. Sawpan, J. Jayaraman, and A. Fernyhough, "Influence of loading rate, alkali fibre treatment and crystallinity on fracture toughness of random short hemp fibre reinforced polylactide bio-composites," Composites Part A: Applied Science and Manufacturing, vol. 42, no. 9, pp. 1148-1156, 2011.

[117] M. Jawaid, H. P. S. Abdul Khalil, A. Hassan, R. Dungani, and A. Hadiyane, "Effect of jute fibre loading on tensile and dynamic mechanical properties of oil palm epoxy composites," Composites Part B: Engineering, vol. 45, no. 1, pp. 619-624, 2013.

[118] K. Mylsamy and I. Rajendran, "Influence of alkali treatment and fibre length on mechanical properties of short Agave fibre reinforced epoxy composites," Materials \& Design, vol. 32, no. 8-9, pp. 4629-4640, 2011.

[119] H. U. Zaman and M. Beg, "Preparation, structure, and properties of the coir fiber/polypropylene composites," Journal of Composite Materials, vol. 48, no. 26, pp. 32933301, 2014.

[120] B. Wang, S. Panigrahi, L. Tabil, and W. Crerar, "Pre-treatment of flax fibers for use in rotationally molded biocomposites," Journal of Reinforced Plastics and Composites, vol. 26, no. 5, pp. 447-463, 2007.

[121] G. W. Beckermann and K. L. Pickering, "Engineering and evaluation of hemp fibre reinforced polypropylene composites: fibre treatment and matrix modification," Composites Part A: Applied Science and Manufacturing, vol. 39, no. 6, pp. 979-988, 2008.

[122] M. M. Kabir, H. Wang, K. T. Lau, F. Cardona, and T. Aravinthan, "Mechanical properties of chemically-treated hemp fibre reinforced sandwich composites," Composites Part B: Engineering, vol. 43, no. 2, pp. 159-169, 2012.

[123] M. Bera, R. Alagirusamy, and A. Das, "A study on interfacial properties of jute-PP composites," Journal of Reinforced Plastics and Composites, vol. 29, no. 20, pp. 3155-3161, 2010.

[124] M. A. Sawpan, K. L. Pickering, and A. Fernyhough, "Improvement of mechanical performance of industrial hemp fibre reinforced polylactide biocomposites," Composites Part A: Applied Science and Manufacturing, vol. 42, no. 3, pp. 310-319, 2011.

[125] M. M. Kabir, H. Wang, K. T. Lau, and F. Cardona, "Chemical treatments on plant-based natural fibre reinforced polymer composites: an overview," Composites Part B: Engineering, vol. 43, no. 7, pp. 2883-2892, 2012.

[126] M. S. Islam, K. L. Pickering, and N. J. Foreman, "Influence of alkali treatment on the interfacial and physico-mechanical properties of industrial hemp fibre reinforced polylactic acid composites," Composites Part A: Applied Science and Manufacturing, vol. 41, no. 5, pp. 596-603, 2010.

[127] R. Vijay, D. Lenin Singaravelu, A. Vinod et al., "Characterization of raw and alkali treated new natural cellulosic fibers from Tridax procumbens," International Journal of Biological Macromolecules, vol. 125, no. 15, pp. 99-108, 2019.

[128] N. Sgriccia, M. C. Hawley, and M. Misra, "Characterization of natural fiber surfaces and natural fiber composites," Composites Part A: Applied Science and Manufacturing, vol. 39, no. 10, pp. 1632-1637, 2008.

[129] N. P. G. Suardana, Y. Piao, and J. K. Lim, "Mechanical properties of hemp fibers and hemp/pp composites: effects of chemical surface treatment," Materials Physics and Mechanics, vol. 11, no. 1, pp. 1-8, 2011. 
[130] Y. Xu, S. Kawata, K. Hosoi, T. Kawai, and S. Kuroda, "Thermomechanical properties of the silanized-kenaf/polystyrene composites," Express Polymer Letters, vol. 3, no. 10, pp. 657-664, 2009.

[131] M. S. Sreekala and S. Thomas, "Effect of fibre surface modification on water-sorption characteristics of oil palm fibres," Composites Science and Technology, vol. 63, no. 6, pp. 861-869, 2003.

[132] S. Srisuwan, N. Prasoetsopha, N. Suppakarn, and P. Chumsamrong, "The effects of alkalized and silanized woven sisal fibers on mechanical properties of natural rubber modified epoxy resin," Energy Procedia, vol. 56, pp. 19-25, 2014.

[133] P. J. Jandas, S. Mohanty, and S. K. Nayak, "Mechanical properties of surface-treated banana fiber/polylactic acid biocomposites: a comparative study of theoretical and experimental values," Journal of Applied Polymer Science, vol. 127, no. 5, pp. 4027-4038, 2013.

[134] Y. Seki, "Innovative multifunctional siloxane treatment of jute fiber surface and its effect on the mechanical properties of jute/thermoset composites," Materials Science and Engineering: $A$, vol. 508, no. 1-2, pp. 247-252, 2009.

[135] K. Sever, M. Sarikanat, Y. Seki, G. Erkan, and Ü. H. Erdoğan, "The mechanical properties of $\gamma$-methacryloxypropyltrimethoxy silane-treated jute/polyester composites," Journal of Composite Materials, vol. 44, no. 15, pp. 1913-1924, 2010.

[136] S. Potjanart, T. Thiranan, S. Wirasak, and C. Rungsima, "Modification of pineapple leaf fiber surfaces with silane and isocyanate for reinforcing thermoplastic," Journal of Thermoplastic Composite Materials, vol. 30, no. 10, pp. 13441360, 2016.

[137] Y. Xie, C. A. S. Hill, Z. Xiao, H. Militz, and C. Mai, "Silane coupling agents used for natural fiber/polymer composites: a review," Composites Part A: Applied Science and Manufacturing, vol. 41, no. 7, pp. 806-819, 2010.

[138] H. P. S. A. Khalil, H. Ismail, H. D. Rozman, and M. N. Ahmad, "The effect of acetylation on interfacial shear strength between plant fibres and various matrices," European Polymer Journal, vol. 37, no. 5, pp. 1037-1045, 2001.

[139] A. K. Bledzki, A. A. Mamun, M. Lucka-Gabor, and V. S. Gutowski, "The effects of acetylation on properties of flax fibre and its polypropylene composites," Express Polymer Letters, vol. 2, no. 6, pp. 413-422, 2008.

[140] S. Joseph, M. S. Sreekala, Z. Oommen, P. Koshy, and S. Thomas, "A comparison of the mechanical properties of phenol formaldehyde composites reinforced with banana fibres and glass fibres," Composites Science and Technology, vol. 62, no. 14, pp. 1857-1868, 2002.

[141] H. N. Dhakal, Z. Y. Zhang, M. O. W. Richardson, and O. A. Z. Errajhi, "The low velocity impact response of nonwoven hemp fibre reinforced unsaturated polyester composites," Composite Structures, vol. 81, no. 4, pp. 559-567, 2007.

[142] G. T. Mahesha, S. B. Shenoy, V. M. Kini, and N. H. Padmaraja, "Effect of fiber treatments on mechanical properties of Grewia serrulata bast fiber reinforced polyester composites," Materials Today Proceedings, vol. 5, no. 1, pp. 138-144, 2018.

[143] S. O. Amiandamhen, M. Meincken, and L. Tyhoda, "The effect of chemical treatments of natural fibres on the properties of phosphate-bonded composite products," Wood Science and Technology, vol. 52, no. 3, pp. 653-675, 2018.
[144] J. Kuruvilla, T. Sabu, and C. Pavithran, "Effect of chemical treatment on the tensile properties of short sisal fibrereinforced polyethylene composites," Polymers, vol. 37, no. 23, pp. 5139-5149, 1996.

[145] X. Li, S. A. Panigrahi, L. G. Tabil, and W. J. Crerar, "Flax fiber-reinforced composites and the effect of chemical treatments on their properties," in Proceedings of the CSAE: ASAE Annual Intersection Meeting, Winnipeg, Canada, September 2004.

[146] S. A. Paul, K. Joseph, G. D. G. Mathew, L. A. Pothen, and S. Thomas, "Influence of polarity parameters on the mechanical properties of composites from polypropylene fiber and short banana fiber," Composites Part A: Applied Science and Manufacturing, vol. 41, no. 10, pp. 1380-1387, 2010.

[147] J. K. Sam, B. M. Jin, H. K. Gue, and Ha Chang-Sik, "Mechanical properties of polypropylene/natural fiber composites: comparison of wood fiber and cotton fiber," Polymer Testing, vol. 27, no. 7, pp. 801-806, 2008.

[148] I. O. Eze, I. O. Igwe, and O. Ogbobe, "Effect of hydrogen peroxide treated pineapple leaf powder on mechanical properties of high density polyethylene composites," European Journal of Advances in Engineering and Technology, vol. 4, no. 8, pp. 617-622, 2017.

[149] R. Meeske, H. H. Meissner, and J. P. Pienaar, "The upgrading of wheat straw by alkaline hydrogen peroxide treatment; the effect of $\mathrm{NaOH}$ and $\mathrm{H}_{2} \mathrm{O}_{2}$ on the site and extent of digestion in sheep," Animal Feed Science and Technology, vol. 40, no. 23, pp. 121-133, 1993.

[150] S. Priya and S. K. Tiwari, "Effect of various chemical treatments on the damping property of jute fibre," International Journal of Advanced Mechanical Engineering, vol. 4, no. 4, pp. 413-424, 2014.

[151] A. R. Nurinani, A. I. Nor, Z. Norhazlin, R. Marwah, and S. Wan Zuhainis, "The influence of chemical surface modification of kenaf fiber using hydrogen peroxide on the mechanical properties of biodegradable kenaf fiber/poly (lactic acid) composites," Molecules, vol. 19, no. 3, pp. 2957-2968, 2014.

[152] V. Vilay, M. Mariatti, R. M. Taib, and M. Todo, "Effect of fiber surface treatment and fiber loading on the properties of bagasse fiber-reinforced unsaturated polyester composites," Composites Science and Technology, vol. 68, no. 3-4, pp. 631-638, 2008.

[153] M. S. Sreekala, M. G. Kumaran, and S. Thomas, "Water sorption in oil palm fiber reinforced phenol formaldehyde composites," Composites Part A: Applied Science and Manufacturing, vol. 33, no. 6, pp. 763-777, 2002.

[154] S. Kadem, R. Irinislimane, and N. Belhaneche-Bensemra, "Novel biocomposites based on sunflower oil and alfa fibers as renewable resources," Journal of Polymers and the Environment, vol. 26, no. 7, pp. 3086-3096, 2018.

[155] V. A. Patel and P. H. Parsania, "Performance evaluation of alkali and acrylic acid treated-untreated jute composites of mixed epoxy-phenolic resins," Journal of Reinforced Plastics and Composites, vol. 29, no. 5, pp. 725-730, 2010.

[156] A. S. Singha and R. K. Rana, "Chemically induced graft copolymerization of acrylonitrile onto lignocellulosic fibers," Journal of Applied Polymer Science, vol. 124, no. 3, pp. 1891-1898, 2012.

[157] S. Mishra, S. S. Tripathy, M. Misra, A. K. Mohanty, and S. K. Nayk, "Novel eco-friendly biocomposites: biofiber reinforced biodegradable polyester amide composites-fabrication and properties evaluation," Journal of Reinforced Plastics and Composites, vol. 21, no. 1, pp. 55-70, 2002. 
[158] T. O. Aborode, O. D. Ogundele, and S. O. Thompson, "Graft copolymerization of acrylonitrile on allylated pineapple (ananancomosus) fiber using redox pair of potassium permanganate and N-butylacetate," International Journal of Current Research in Applied Chemistry \& Chemical Engineering, vol. 3, no. 2, pp. 1-7, 2019.

[159] V. K. Thakur, M. K. Thakur, and R. K. Gupta, "Graft copolymers of natural fibers for green composites," Carbohydrate Polymers, vol. 104, pp. 87-93, 2014.

[160] Q. Wulin, Z. Farao, T. Endo, and H. Takahiro, "Isocyanate as a compatibilizing agent on the properties of highly crystalline cellulose/polypropylenecomposites," Journal of Materials Science, vol. 40, no. 14, pp. 3607-3614, 2005.

[161] K. Joseph, S. Thomas, and C. Pavithran, "Effect of chemical treatment on the tensile properties of short sisal fibrereinforced polyethylene composites," Polymer, vol. 37, no. 23, pp. 5139-5149, 1996.

[162] C. K. Hong, N. Kim, S. L. Kang et al., "Mechanical properties of maleic anhydride treated jute fibre/polypropylene composites," Plastics, Rubber and Composites, vol. 37, no. 7, pp. 325-330, 2008.

[163] J. Gassan and A. K. Bledzki, "Possibilities to improve the properties of natural fiber reinforced plastics by fiber modification-ute polypropylene composites," Applied Composite Materials, vol. 7, no. 5-6, pp. 373-385, 2000.

[164] P. Ming-Zhu, Z. Ding-Guo, D. James, and S. Y. Zhang, "Preparation and properties of wheat straw fiber-polypropylene composites I: investigation of surface treatments on the wheat straw fiber," Journal of Applied Polymer Science, vol. 114, no. 5, pp. 3049-3056, 2009.

[165] L. Qingxiu and M. M. Laurent, "Effectiveness of maleated and acrylic acid-functionalized polyolefin coupling agents for HDPEwood- flour composites," Journal of Thermoplastic Composite Materials, vol. 16, pp. 551-564, 2003.

[166] S. Mohanty, S. K. Nayak, S. K. Verma, and S. S. Tripathy, "Effect of MAPP as coupling agent on the performance of sisal-PP composites," Journal of Reinforced Plastics and Composites, vol. 23, no. 18, pp. 2047-2063, 2004.

[167] S. Mishra, J. B. Naik, and Y. P. Patil, "The compatibilising effect of maleic anhydride on swelling and mechanical properties of plant-fiber-reinforced novolac composites," Composites Science and Technology, vol. 60, no. 9, pp. 1729-1735, 2000.

[168] X. Li, J. Zhang, J. He, D. Jeevan Prasad Reddy, and A. Varada Rajulu, "Tensile properties of hildegardia fibers reinforced polypropylene biocomposites," Journal of Composite Materials, vol. 44, no. 14, pp. 1681-1687, 2010.

[169] K. C. Sanjay, R. K. Khandal, U. Ramagopal, and G. Aloke Kumar, "Influence of varying fiber lengths on mechanical, thermal, and morphological properties of MA-g-PP compatibilized and chemically modified short pineapple leaf fiber reinforced polypropylene composites," Journal of Applied Polymer Science, vol. 3, no. 2, pp. 3750-3756, 2019.

[170] S. Mohanty, S. Verma, and S. Nayak, "Dynamic mechanical and thermal properties of MAPE treated jute/HDPE composites," Composites Science and Technology, vol. 66, no. 3-4, pp. 538-547, 2006.

[171] S. Mohanty and S. K. Nayak, "Interfacial, dynamic mechanical, and thermal fiber reinforced behavior of MAPE treated sisal fiber reinforced HDPE composites," Journal of Applied Polymer Science, vol. 102, no. 4, pp. 3306-3315, 2006.

[172] K. B. Adhikary, S. Pang, and M. P. Staiger, "Dimensional stability and mechanical behaviour of wood-plastic composites based on recycled and virgin high-density polyethylene (HDPE)," Composites Part B: Engineering, vol. 39, no. 5, pp. 807-815, 2008.

[173] D. P. Ferreira, J. Cruz, and R. Fangueiro, "Surface modification of natural fibers in polymer composites," in Green Composites for Automotive Applications, G. Koronis and A. Silva, Eds., Woodhead Publishing, Kidlington, UK, pp. 3-41, 2019.

[174] S. Mouhoubi, M. E. H. Bourahli, H. Osmani, and S. Abdeslam, "Effect of alkali treatment on alfa fibers behavior," Journal of Natural Fibers, vol. 14, no. 2, pp. 239-249, 2016.

[175] L.-J. Yang, A. N. Haq, and L. Nagarajan, "Proceedings of the ICDMC 2019," Lecture Notes in Mechanical Engineering, Springer, Berlin, Germany, 2020.

[176] Y. Liu, X. Lv, J. Bao et al., "Characterization of silane treated and untreated natural cellulosic fibre from corn stalk waste as potential reinforcement in polymer composites," Carbohydrate Polymers, vol. 218, pp. 179-187, 2019.

[177] Y. Liu, J. Xie, N. Wu, L. Wang, Y. Ma, and J. Tong, "Influence of silane treatment on the mechanical, tribological and morphological properties of corn stalk fiber reinforced polymer composites," Tribology International, vol. 131, pp. 398-405, 2019.

[178] J. T. W. Jappes and I. Siva, "Studies on the influence of silane treatment on mechanical properties of coconut sheathreinforced polyester composite," Polymer-plastics Technology and Engineering, vol. 50, no. 15, pp. 1600-1605, 2011.

[179] H. Kim, K. Okubo, T. Fujii, and K. Takemura, "Influence of fiber extraction and surface modification on mechanical properties of green composites with bamboo fiber," Journal of Adhesion Science and Technology, vol. 27, no. 12, pp. 1348-1358, 2013.

[180] C. Y. Lai, S. M. Sapuan, M. Ahmad, N. Yahya, and K. Z. H. M. Dahlan, "Mechanical and electrical properties of coconut coir fiber-reinforced polypropylene composites," Polymer-Plastics Technology \& Engineering, vol. 44, no. 4, pp. 619-632, 2005.

[181] D. Sampathkumar, R. Punyamurth, S. C. Venkateshappa, and B. Bennehalli, "Effect of chemical treatment on water absorption of areca fiber," Journal of Applied Sciences Research, vol. 8, no. 11, pp. 5298-5305, 2012.

[182] A. Bessadok, S. Marais, F. Gouanvé et al., "Effect of chemical treatments of Alfa (Stipatenacissima) fibres on water-sorption properties," Composites Science and Technology, vol. 67, no. 3-4, pp. 685-697, 2007.

[183] K. Mylswamy and I. Rajendran, "Physical, chemical and mechanical properties of raw and treated agave Americana fibers," Journal of Reinforced Plastics and Composites, vol. 29, no. 19, pp. 2925-2935, 2010.

[184] E. T. N. Bisanda, "The effect of alkali treatment on the adhesion characteristics of sisal fibers," Applied Composite Materials, vol. 7, no. 5-6, pp. 331-339, 2000.

[185] T. Väisänen, A. Haapala, R. Lappalainen, and L. Tomppo, "Utilization of agricultural and forest industry waste and residues in natural fiber-polymer composites: a review," Waste Management, vol. 54, pp. 62-73, 2016.

[186] Y. Yu, H. Wang, F. Lu, G. Tian, and J. Lin, "Bamboo fibers for composite applications: a mechanical and morphological investigation," Journal of Materials Science, vol. 49, no. 6, pp. 2559-2566, 2014.

[187] S. Sharma and A. Kumar, "Lignin (Biosynthesis and Transformation for Industrial Applications)," Springer Series on Polymer and Composite Materials, Springer, Berlin, Germany, 2020. 
[188] D. S. Bajwa, G. Pourhashem, A. H. Ullah, and S. G. Bajwa, "A concise review of current lignin production, applications, products and their environmental impact," Industrial Crops and Products, vol. 139, Article ID 111526, 2019.

[189] J. Karthäuser, V. Biziks, C. Mai, and H. Militz, "Lignin and lignin-derived compounds for wood applications-a review," Molecules, vol. 26, no. 9, p. 2533, 2021.

[190] M. Gupta, "Investigations on jute fibre-reinforced polyester composites: effect of alkali treatment and poly(lactic acid) coating," Journal of Industrial Textiles, vol. 49, no. 7, pp. 923-942, 2020. 